\title{
PEMBERDAYAAN MASYARAKAT NELAYAN DI PESISIR PANTAI BLANAKAN KABUPATEN SUBANG
}

\author{
Oleh : Zaenal Abidin, AS \\ Dosen Jurusan Ilmu Pemerintahan FISIP Universitas Jenderal Achmad Yani \\ e-mail :m.zaenal27@gmail.com
}

\begin{abstract}
Abstrak
Pemberdayaan adalah salah satu konsep didalam meningkatkan kualitas, baik kualitas sumberdaya manusia atau kualitas perekonomian. Masyarakat nelayan sebagai masyarakat yang memanfaatkan potensi laut dan pesisir laut sebagai pendapatan perekonomian tidak dapat disandingkan dengan masyarakat ekonomi disektor lain, seperti sector pertanian, sector perindustrian dll. Upaya pemberdayaan sangat diperlukan didalam mendongkrak persoalanpersoalan yang ada di masyarakat pesisir (Nelayan) sebagai upaya meningkatkan kehidupan mereka dan dapat disandingkan dengan sector perekonomian lain. Desa Blanakan Subang sebagai salah satu wilayah pesisir laut, memiliki potensi yang sangat baik dalam meningkatkan potensi kelautan yang ada. Dimana wilayah ini memiliki sarana dan prasarana yang baik dibandingkan dengan wilayah pesisir lain. Namun persoalan-persoalan yang menghambat proses pemberdayaan pasti selalu ada. Dalam penelitian ini, peneliti mencoba mencari ada atau tidaknya konsep pemberdayaan yang dilakukan diwilayah yang berkaitan dengan masyarakat pesisir (Nelayan), dan permasalahan apa saja yang menjadi penghambat dan pendukung didalam mensukseskan proses pemberdayaan masyarakat nelayan. Proses pemberdayaan masyarakat nelayan di Desa Blanakan Kabupaten Subang belum berjalan dengan baik, proses pemberdayaan yang dilakukan di desa ini banyak dilakukan oleh koperasi. Permasalahan yang timbul adalah ketika koperasi melakukan pemberdayaan masyarakat nelayan hanya dilakukan kepada mereka-mereka yang memiliki perahu dan tidak sampai kepada masyarakat nelayan buruh. Pemerintah desa melalui LPMDes (Lembaga Pemberdayaan Desa) tidak melakukan pemberdayaan kepada masyarakat nelayan karena menganggap proses pemberdayaan sudah dilakukan oleh koperasi. Permasalahan yang ada didalam proses pemberdayaan di Desa Blanakan Subang ini hanya kurangnya koordinasi yang dilakukan antara pemerintah desa melalui LPMDes dengan pihak Koperasi, karena persoalan ini yang menghambat proses pemberdayaan di wilayah ini tidak ada, kecuali persoalan koordinasi. Dimana peneliti berpendapat dengan adanya proses koordinasi yang mereka lakukan akan mempermudah didalam mendisain dan melakukan proses pemberdayaan, sehingga tidak ada lagi tumpang tindih kewenangan.

Kata Kunci : Pemberdayaan, Nelayan, LPMDes (Lembega Pemberdayaan Desa).
\end{abstract}

\section{PEMBERDAYAAN MASYARAKAT NELAYAN DI PESISIR PANTAI BLANAKAN KABUPATEN SUBANG}

\section{PENDAHULUAN}

\section{Latar Belakang Penelitian.}

Indonesia merupakan Negara

bahari dan Negara kepulauan terbesar didunia yang memiliki garis pantai terpanjang kedua didunia setelah kanada $81.000 \mathrm{Km}$. Indonesia yang sebagian besar wilayahnya berada di pesisir dan memiliki potensi kelautan yang cukup besar, seharusnya mampu mensejahterakan 
kehidupan masyarakatnya terutama dalam hal pemanfaatan dan pengelolaan potensi kelautan yang dimilikinya. Namun pada kenyataannya, kehidupan masyarakat pesisir selalu dilanda kemiskinan, bahkan kehidupan pesisir sering di identikan dengan kemiskinan. Kesulitan untuk melepakskan diri dari belenggu kemiskinan karena mereka didera oleh beberapa keterbatasan dibidang kualitas sumberdaya manusia, akses dan penguasaan teknolgi, pasar, dan modal. Kebijakan dan implementasi programprogram pembangunan untuk masyarakat pesisir hingga saat ini dapat dikatakan masih belum optimal dalam memutuskan rantai kemiskinan dan meningkatkan kesejahteraan mereka (Kusnadi, 2007).

Masyarakat pesisir dikatagorikan sebagai kelompok orang yang mendiami disuatu wilayah pesisir dan sumber kehidupan perekonomiannya bergantung pada pemanfaatan sumber daya laut dan pesisir. Masyarakat pesisir sendiri bukan hanya nelayan, melainkan juga pemberdayaan ikan, pengolah ikan, bahkan pedagang ikan. Sedangkan Kemiskinan masyarakat pesisir dikategorikan sebagai kemiskinan struktural, kemiskinan super struktural, dan kemiskinan cultural. Bebrapa pakar ekonomi mengatakan bahwa nelyan tetap mau untuk tinggal dalam lingkaran kemiskinn karena kehendaknya untuk menjalani hidup.
Mereka memperoleh kepuasan tersendiri dari hasil menangkap ikan.

Kesulitan melepaskan diri dari belenggu kemiskinan karena mereka didera oleh beberapa keterbatasan di bidang kualitas sumberdaya manusia, akses dan penguasaan teknologi, pasar, dan modal. Kebijakan dan implementasi program-program pembangunan untuk masyarakat di kawasan pesisir hingga saat ini masih belum optimal dalam memutus mata rantai belenggu kemiskinan dan meningkatkan kesejahteraan mereka (Kusnadi, 2009).

Masyarakat pesisir desa Blanakan merupakan masyarakat yang berlokasi di pesisir utara laut jawa, dimana mata pencahariannya menggantungkan pada sektor pertanian, pembudidayaan ikan dan udang (tambak), dan nelayan. Dari semua sektor yang ada, semuanya masih dijalankan scara tradisional. Pendekatan kelembagaan sebagai basis dalam kegiatan pemberdayaan memiliki beberapa keuntungan sebagai berikut: memperbesar kemampuan sumberdaya dan meningkatkan skala usaha ekonomi kolektif yang dimiliki masyarakat, (2) meningkatkan posisi tawar kolektif dalam mengakses modal, pasar, teknologi, dan kebijakan, mengembangkan kemampuan koordinasi dan kerja sama kemitraan dalam pengelolaan kegiatan 
ekonomi kolektif untuk mendukung dinamika ekonomi kawasan, dan (4) memudahkan pengontrolan terhadap perjalanan ekonomi bersama (Kusnadi,2009).

Bertolak dari uraian yang telah dikemukakan tersebut di atas, maka dapat dikatakan bahwa fenomena seperti itu sangat menarik untuk diteliti, oleh karenanya penelitian ini akan mengkaji secara kritis atas pertanyaan bagaimana peran lembaga-lembaga tersebut dapat menjawab permasalahan masyarakat pesisir (Nelayan) di desa Blanakan, Kecamatan Blanakan, Kabupaten Subang Jawa Barat. Dimana dalam Undangundang desa No. 6 Tahun 2014 telah di jelaskan secara jelas kewenangan yang dimiliki oleh desa, dimana didalam kewenangan tersebut dijelaskan tentang hak dan kewajiban yang melekat terhadap pemanfaatan potensi yang ada di daerahnya ( pasal 26 dan pasal 27), yang mana dalam penelitian ini peneliti ingin mengetahui sejauh mana peran pemerintah Desa didalam melaksanakan pemanfaatan potensi yang dimilikinya, dalam hal ini adalah permasalahan pemberdayaan masyarakat (Nelayan).

\section{Perumusan Masalah.}

Permasalahan pemberdayaan terhadap wilayah-wilayah pesisir yang diidentikan dengan wilayah Miskin yang menggantungkan diri di bidang pertanian, nelayan dan pembudidayaan ikan dan udang sebagai wilayah yang kurang maju secara ekonomi bila dibandingkan dengan sektor-sektor perekonominan yang lain.

Nelayan (khususnya nelayan buruh dan nelayan tradisional) merupakan kelompok masyarakat yang dapat digolongkan sebagai lapisan sosial yang paling miskin diantara kelompok masyarakat lain di sektor pertanian.

Penelitian ini membatasi kajianya terhadap peran yang dijalankan oleh Lembaga Pemberdayaan Masyarakat Desa (LPMDes) dalam membina dan meningkatkan kualitas nelayan di Desa Blanakan, Kec Blanakan kabupaten Subang Jawa Barat. Hal ini didasarkan sejauh mana lembaga ini dapat menghantarkan masyarakat pesisir didalam meningkatkan daya saing dan daya guna yang dapat disejajarkan dengan sektorsektor perekonomian lainnya.

Berdasarkan konsep dan pertanyaan yang disajikan sebagai perumusan masalah, peneliti menyajikan hipotesis terkait dengan permasalahan yang diangkat yakni : mengkaji Peranan yang dilakukan oleh Lembaga Pemberdayaan Msayarakat Desa didalam melakukan pemberdayaan masyarakat 
pesisir (Nelayan) Blanakan didalam mengofimalkan tarap kehidupan nelayan baik secara perekonomian, sosial budaya maupun didalam peningkatan dibidang pengetahuan (pendidikan), agar dapat bersaing dengan sektor perekonomian yang lain dan nelayan tidak lagi dipandang sebagai masyarakat yang lemah secara perekonomian.

\section{Tujuan Penelitian.}

Tujuan dari penelitian ini adalah :

1. Untuk mengidentifikasi dan menguraikan secara jelas dan mendalam mengenai peran Lembaga Pemberdayaan Msayarakat Desa Blanakan dalam keikut sertaannya terlibat dalam peningkatan kehidupan masyarakat Pesisir Blanakan (nelayan) sebagai bagian dari tugas pokok dan fungsinya.

2. Untuk memberikan masukan bagi pihak terkait baik Lembaga Pemberdayaan Msayarakat Desa Maupun Pihak-pihak terkait lainnya didalam upaya untuk meningkatkan perekonomian mandiri yang berasal dari desa (sektor Kelautan (Nekayan)).

\section{Manfaat Penelitian}

Manfaat yang ingin dicapai dari penelitian ini adalah :

1. memberikan gambaran tentang potensi-potensi yang dimiliki daerah dalam hal ini desa didalam pemberdayaan khususnya wilayah pesisir, sehingga dapat dijadikan reverensi didalam proses pemberdayaan desa dalam melihat tantangan dan hambatan didalam proses pemberdayaan wilayah pesisir.

2. Dapat Juga dijadikan sebagai acuan awal yang dapat dimanfaatkan oleh pemerintah didalam menentukan sebuah kebijakan yang akan dikeluarkan sehingga dapat dikatakan sesuai dengan kebutuhan masyarakatnya, dalam hal ini adalah masyarakat pesisir (nelayan).

\section{TINJAUAN PUSTAKA}

\section{Konsep Pemberdayaan}

Konsep pemberdayaan dalam wacana pembangunan masyarakat selalu dihubungkan dengan konsep mandiri, partisipasi, jaringan kerja, dan keadilan. Pada dasarnya, pemberdayaan diletakkan pada kekuatan tingkat individu dan sosial. Menurut Hikmat (2006), pemeberdayaan 
diartikan sebagai pemahaman secara psikologis pengaruh kontrol individu terhadap keadaan sosial, kekuatan politik, dan hak-haknya menurut undang-undang (Hikmat, 2006).

Sementara itu menurut Suharto (2005) Pemberdayaan merujuk pada kemampuan orang, khususnya kelompok rentan dan lemah sehingga mereka memiliki kekuatan atau kemampuan dalam (a) memenuhi kebutuhan dasarnya sehingga mereka memiliki kebebasan (freedom), dalam arti bukan saja bebas dalam mengemukakan pendapat, melainkan bebas dari kelaparan, bebas dari kebodohan, bebas dari kesakitan; (b) menjangkau sumber-sumber produktif yang memungkinkan mereka dapat meningkatkan pendapatannya dan memperoleh barang-barang dan jasa-jasa yang mereka perlukan; dan (c) berpartisipasi dalam proses pembangunan dan keputusankeputusan yang mempengaruhi mereka (Suharto, 2005).

\footnotetext{
Pemberdayaan adalah sebuah proses dan tujuan. Sebagai proses, pemberdayaan adalah serangkaian kegiatan untuk memperkuat kekuasaan atau keberdayaan kelompok lemah dalam masyarakat, termasuk individu-individu yang mengalami masalah kemiskinan. Sebagai tujuan, maka pemberdayaan merujuk pada keadaan atau hasil yang
}

ingin dicapai oleh sebuah perubahan sosial; yaitu masyarakat yang berdaya, memiliki kekuasaan atau mempunyai pengetahuan dan kemampuan dalam memenuhi kebutuhan hidupnya baik yang bersifat fisik, ekonomi maupun sosial seperti memiliki kepecayaan diri, mampu menyampaikan aspirasi, mempunyai mata pencaharian, berpartisipasi dalam kegiatan sosial, dan mandiri dalam melaksanakan tugas-tuagas kehidupannya. Menurut Ife (1995), pemberdayaan memuat dua pengertian kunci, yakni kekuasaan dan kelompok lemah. Kekuasaan disini diartikan bukan hanya menyangkut kekuasaan politik dalam arti sempit, melainkan kekuasaan atau penguasaan klien atas:

1) Pilihan-pilihan personal dan kesempatan-kesempatan hidup: kemampuan dalam membuat keputusan-keputusan mengenai gaya hidup, tempat tinggal, pekerjaan.

2) Pendefinisian kebutuhan, kemampauan menentukan kebutuhan selaras dengan aspirasi dan keiniginannya.

3) Ide atau gagasan, kemampuan mengekspresikan dan menyumbangkan gagasan dalam 
suatu forum atau diskausi secara bebas tanpa tekanan.

4) Lembaga-lembaga, kemampuan menjangkau, menggunakan da mempegaruhi pranata-pranata masyarakat, seperti lembagalembaga sosial, pendidikan dan kesehatan.

5) Sumber-sumber; kemampuan memobilisasi sumber-sumber formal, informal dan kemasyarakatan.

6) Aktivitas ekonomi, kemampuan memanfaatkan dan mengelola mekanisme prodiuksi, distribusi, dan pertukaran barang serta jasa.

7) Reproduksi, kemampuan dalam kaitannya dengan proses kelahiran, perawatan anak, pendidikan dan sosialisasi, dan tujan (Ife, 1995).

Sebagai proses, pemberdayaan adalah serangkaian kegiatan untuk memperkuat kekuasaan atau keberdayaan kelompok lemah dalam masyarakat, termasuk individu-individu yang mengalami masalah kemiskinan. Sebagai tujuan, maka pemberdayaan menunjuk pada keadaan atau hasil yang ingin dicapai oleh sebuah perubahan sosial; yaitu masyarakat yang berdaya, memiliki kekuasaan atau mempunyai kemampuan dan pengetahuan dalam memenuhi kebutuhan hidupnya baik yang bersifat fisik, ekonomi maupun sosial, seperti memiliki kepercaayan diri, mampu menyampaikan aspirasi, mempunyai mata pencaharian, berpartisipasi dalam kegiatan sosial, dan mandiri dalam melaksanakan tugas-tugas kehidupannya. Pengertian pemberdayaan sebagai tujuan seringkali digunakan sebagai indikator keberhasilan pemberdayaan sebagai sebuah proses.

\section{Konteks Masyarakat Nelayan}

Secara geografis, masyarakat nelayan adalah masyarakat yang hidup, tumbuh, dan berkembang di kawasan pesisir, yakni suatu kawasan transisi antara wilayah darat dan wilayah laut. Sebagai suatu sistem, masyarakat nelayan terdiri atas kategori-kategori sosial yang membentuk kekuatan sosial. Mereka juga memiliki sistem nilai dan simbol-simbol kebudayaan sebagai referensi perilaku mereka sehari-hari. Faktor budaya ini menjadi pembeda masyarakat nelayan dari kelompok masyarakat lainnya. Sebagian besar masyarakat pesisir, baik langsung maupun tidak langsung, menggantungkan kelangsungan hidupnya dari mengelola potensi sumberdaya perikanan. Mereka menjadi komponen utama konstruksi masyarakat maritim Indonesia (Kusnadi, 2009)

Menurut Kusnadi, ada dua sebab yang menyebabkan kemiskinan nelayan, 
yaitu sebab yang bersifat internal dan bersifat eksternal. Kedua sebab tersebut saling berinteraksi dan melengkapi. Sebab kemiskinan yang bersifat internal berkaitan erat dengan kondisi internal sumber daya manusia nelayan dan aktivitas kerja mereka. Sebab-sebab internal ini mencakup masalah : (1) keterbatasan kualitas sumber daya manusia nelayan, (2) keterbatasan kemampuan modal usaha dan teknologi penangkapan, (3) hubungan kerja (pemilik perahunelayan buruh) dalam organisasi penangkapan yang dianggap kurang menguntungkan nelayan buruh, (4) kesulitan melakukan diversifikasi usaha penangkapan, (5) ketergantungan yang tinggi terhadap okupasi melaut, dan (6) gaya hidup yang dipandang boros sehingga kurang berorientasi ke masa depan. Sebab kemiskinan yang bersifat eksternal berkaitan dengan kondisi di luar diri dan aktivitas kerja nelayan. Sebab-sebab eksternal ini mencakup masalah : (1) kebijakan pembangunan perikanan yang lebih berorientasi pada produktivitas untuk menunjang pertumbuhan ekonomi nasional dan parsial, (2) sistim pemasaran hasil perikanan yang lebih menguntungkan pedagang perantara, (3) kerusakan ekosistem pesisir dan laut karena pencemaran dari wilayah darat, praktik penangkapan dengan bahan kimia, pengrusakan terumbu karang, dan konservasi hutan bakau di kawasan pesisir,
(4) penggunaan peralatan tangkap yang tidak ramah lingkungan, (5) penegakan hukum yang lemah terhadap perusak lingkungan, (6) terbatasnya teknologi pengolahan hasil tangkapan pascapanen, (7) terbatasnya peluang-peluang kerja di sektor non perikanan yang tersedia di desadesa nelayan, (8) kondisi alam dan fluktuasi musim yang tidak memungkinkan nelayan melaut sepanjang tahun, dan (9) isolasi geografis desa nelayan yang mengganggu mobilitas barang, jasa, modal dan manusia (Kusnadi, 2003).

Selanjutnya Mulyadi, mengatakan bahwa sesungguhnya, ada dua hal utama yang terkandung dalam kemiskinan, yaitu kerentanan dan ketidakberdayaan (Mulyadi, 2007). Dengan kerentanan yang dialami, orang miskin akan mengalami kesulitan untuk menghadapi situasi darurat. Ini dapat dilihat pada nelayan perorangan misalnya, mengalami kesulitan untuk membeli bahan bakar untuk keperluan melaut. Hal ini disebabkan sebelumnya tidak ada hasil tangkapan yang bisa dijual, dan tidak ada dana cadangan yang dapat digunakan untuk keperluan yang mendesak. Hal yang sama juga dialami oleh nelayan buruh, mereka merasa tidak berdaya dihadapan para juragan yang telah mempekerjakannya, 
meskipun bagi hasil yang diterimanya dirasakan tidak adil.

Keterbatasan kepemilikan aset adalah ciri umum masyarakat nlayan yang

miskin, hal ini tergambar dari kondisi rumah. Rumah nelayan terletak di pantai, di pinggir jalan kampung umumnya merupakan bangunan non parmenen atau semi parmenen, berdinding bambu, berlantai tanah, ventilasi rumah kurang baik sehingga sehari-hari bau anyir ikan menyengat dan meskipun siang hari, di dalam rumah cukup gelap, sementara juru mudi atau juragan jauh lebih baik berbentuk parmenen (Siswanto, 2008).

Sebagai suatu masyarakat yang tinggal di kawasan pesisir, masyarakat nelayan mempunyai karakteristik sosial tersendiri yang berbeda dengan masyarakat yang tinggal di daratan. Di beberapa kawasan pesisir yang relatif berkembang pesat, struktur masyarakatnya bersifat heterogen, memiliki etos kerja tinggi, solidaritas sosial yang kuat, serta terbuka terhadap perubahan dan interaksi sosial. Sekalipun demikian, masalah kemiskinan masih mendera sebagaian masyarakat pesisir, sehingga fakta sosial ini terkesan ironi di tengah-tengah kekayaan sumber daya pesisir dan lautan (Kusnadi,2009).

Seperti juga masyarakat yang lain, masyarakat nelayan menghadapi sejumlah masalah politik, sosial dan ekonomi yang kompleks. Masalah-masalah tersebut diantaranya adalah sebagai beikut: (1) kemiskinan, kesenjangan sosial, dan tekanan-tekanan ekonomi yang datang setiap saat, (2) keterbatasan akses modal, teknologi dan pasar, sehingga mempengaruhi dinamika usaha, (3) kelemahan fungsi kelembagaan sosial ekonomi yang ada, (4) kualitas SDM yang rendah sebagai akibat keterbatasan akses pendidikan, kesehatan,dan pelayanan publik, (5) degradasi sumberdaya lingkungan, baik di kawasan pesisir, laut maupun pulau-pulau kecil, dan (6) belum kuatnya kebijakan yang berorientasi pada kemaritiman sebagai pilar utama pembangunan nasional (Kusnadi, 2009).

Masalah-masalah di atas tidak berdiri sendiri, tetapi saling terkait satu sama lain. Misalnya, masalah kemiskinan. Masalah ini disebabkan oleh hubunganhubungan korelatif antara keterbatasan akses, lembaga ekonomi belum berfungsi, kualitas SDM rendah, degradasi sumber daya lingkungan. Karena itu persoalan penyelesaian kemiskinan dalam masyarakat pesisir harus bersifat integralistik. Kalaupun harus memilih salah satu faktor sebagai basis penyelesaian persoalan kemiskinan, pilihan ini benar-benar menjangkau faktorfaktor yang lain atau menjadi motor untuk 
mengatasi masalah-masalah yang lain. Pilihan demikian memang sulit dilakukan, tetapi harus ditempuh untuk mengefisienkan dan mengoptimalkan sumberdaya yang tersedia yang memang terbatas.

\section{Pengertian dan Penggolongan Nelayan}

Nelayan adalah suatu kelompok masyarakat yang kehidupannya tergantung langsung pada hasil laut, baik dengan cara melakukan penangkapan ataupun budi daya. Mereka pada umumnya tinggal dipantai, sebuah lingkungan pemukiman yang dekat dengan lokasi kegiatannya (Mulyadi, 2007). Nelayan identik dengan keterbatasan aset, lemahnya kemampuan modal, posisi tawar dan akses pasar (Siswanto, 2008). Sesungguhnya, nelayan bukanlah suatu entitas tunggal, mereka terdiri dari beberapa kelompok. Dilihat dari segi pemilikan alat tangkap, nelayan dapat dibedakan menjadi tiga kelompok, yaitu nelayan buruh, nelayan juragan, dan nelayan perorangan. Nelayan buruh adalah nelayan yang bekerja dengan alat tangkap milik orang lain. Sebaliknya, nelayan juragan adalah nelayan yang memiliki alat tangkap yang dioperasikan oleh orang lain. Adapun nelayan perorangan adalah nelayan yang memiliki peralatan tangkap sendiri, dan dalam pengoperasiannya tidak melibatkan orang lain (Mulyadi, 2007)
Nelayan dapat didefinisikan pula sebagai orang atau komunitas orang yang secara keseluruhan atau sebagian dari hidupnya tergantung dari kegiatan menangkap ikan. Beberapa kelompok nelayan memiliki beberapa perbedaan dalam karakteristik sosial dan kependudukan. Perbedaan tersebut dapat dilihat pada kelompok umur, pendidikan status sosial, dan kepercayaan. Dalam satu kelompok nelayan juga sering ditemukan perbedaan kohesi internal, dalam pengertian hubungan diantara sesama nelayan maupun di dalam hubunganbermasyarakat (Widodo dan Saudi, 2006).

Menurut Charles, kelompok nelayan dapat dibagi empat kelompok yaitu: (1) nelayan subsisten (subsistence fishers), yaitu nelayan yang menangkap ikan hanya untuk memenuhi kebutuhan sendiri, (2) nelayan asli (native/indigenous/aboriginal fishers), yaitu nelayan yang sedikit banyak memiliki karakter yang sama dengan kelompok pertama, namun memiliki juga hak untuk melakukan aktivitas secara komersial walaupun dalam skala yang sangat kecil, (3) nelayan rekreasi (recreational/sport fishers), yaitu orangorang yang secara prinsip melakukan kegiatan penangkapan hanya sekadar untuk kesenangan atau berolah raga, dan 
(4) nelayan komersial (commercial fishers), yaitu mereka yang menangkap ikan untuk tujuan komersial atau dipasarkan baik untuk pasar domestik maupun pasar ekspor (Charles, 2001).

\section{Disamping pengelompokan}

tersebut, terdapat beberapa terminologi yang sering digunakan untuk menggambarkan kelompok nelayan, seperti nelayan penuh untuk mereka yang menggantungkan keseluruhan hidupnya dari menangkap ikan; nelayan sambilan untuk mereka yang hanya sebagian dari hidupnya tergantung dari menangkap ikan; juragan untuk mereka yang memiliki sumberdaya ekonomi untuk usaha perikanan seperti kapal dan alat tangkap; dan anak buah kapal untuk mereka yang mengalokasikan waktunya dan memperoleh pendapatan dari hasil mengoperasikan alat tangkap ikan, seperti kapal milik juragan (Widodo dan Suadi, 2006).

\section{Alasan Pemberdayaan Nelayan}

Nelayan tradisional adalah masyarakat kecil, masyarakat miskin yang sudah ada sejak zaman dulu. Salah satu alasan kemiskinan ini adalah rendah produktivitas dan pendapatan nelayan. Secara struktur, nelayan terkungkung dalam kemiskinan. Nelayan tidak berdaya dan tidak punya kekuatan untuk keluar dari kemiskinan. Begitu miskinnya, masyarakat nelayan sering disebut kelompok miskin di anatara yang miskin (the poorest of the poor). Kecuali mereka diberdayakan, ada yang mengangkat mereka berupa memberikan daya dan kekuatan dari luar mereka, maka mereka bias keluar dari kemiskinan. Jika tidak, kemiskinan itu akan tetap ada di antara mereka. Kemiskinan itu akan makin parah, menciptakan kemelaratan massal, dalam berbagai segi dan bidang kehidupan. Diawali dengan kemiskinan secara ekonomi, seterusnya berkembang menjadi kemiskinan dan kemelaratan sosial, budaya, hukum, dan paada akhirnya kemiskinan dalam politik, Suara mereka tidak ada harganya. Dapat dibeli dan dijual dengan harga murah. Ketika suara mereka sudah terbeli, mereka tidak ada apa-apanya lagi. Hanya hidup itu sendiri yang mereka punyai. Hidup yang bermakna bagi mereka sendiri (Dault, 2008)

Menurut Hikmat, mengemukakan bahwa pemberdayaan dapat merupakan salah satu upaya untuk mengaktualisasikan potensi yang sudah dimiliki oleh masyarakat (Hikmat, 2006). Dengan kata lain, keberhasilan pemberdayaan masyarakat dalam konteks pembangunan antara lain bermakna bahwa suatu masyarakat tersebut menjadi bagian dari pelaku pembangunan itu sendiri. Berbagai 
aspek yang perlu diperhatikan dalam pemberdayaan masyarakat, antara lain bagaimana suatu inovasi yang lebih maju dapat bermanfaat bagi masyarakat, bagaimana budaya lokal (termasuk kearifan lokal), bagaimana pula mekanisme pelaksanaan dan pembiayaan pembangunan tersebut.

Atas dasar uraian di atas, pemberdayaan masyarakat nelayan sangat diperlukan. Pemberdayaan masyarakat nelayan diartikan sebagai usaha-usaha sadar yang bersifat terencana, sistematik, dan berkesinambungan untuk membangun kemandirian sosial, ekonomi dan politik masyarakat nelayan dengan mengelola potensi sumberdaya yang mereka miliki untuk mencapai keejahteraan sosial yang bersifat berkelanjutan. Kemandirian masyarakat sangat diperlukan untuk meningkatkan posisi tawar (bergaining position) mereka dalam pembangunan kawasan dan pemanfaatan sumberdaya lingkungan. Dengan demikian, diharapkan pada masa mendatang masyarakat nelayan menjadi subyek pembangunan di daerahnya dan kawasan pesisir memiliki perkembangan ekonomi

yang dinamis. Program pemberdayaan harus bisa mendorong terciptanya mobilitas vertikal masyarakat nelayan (Satria, 2001). Kemandirian masyarakat nelayan merupakan tahapan yang sangat menentukan keberhasilan pemberdayaan secara berkelanjutan. Tanpa kemandirian akan sulit dicapai kesejahteraan sosial. Unsur-unsur kemandirian masyarakat tersebut ditentukan oleh kemampuan ekonomi yang dimiliki, kapasitas politik pembangunan, dan memegang teguh prinsip-prinsip sosial yang diyakini bisa menciptakan tata kehidupan yang lebih baik (Kusnadi, 2009).

\section{Pemberdayaan Masyarakat Secara Partisipasi}

Lahirnya pemikiran pembangunan partisipasi dilatarbelakangi oleh program, proyek, dan kegiatan pembangunan masyarakat yang datang dari atas atau dari luar komunitas. Faktanya, konsep pembangunan ini sering gagal dan tidak sesuai dengan kebutuhan masyarakat lokal. Para praktisi pembangunan juga sering mengalami frustasi terhadap kegagalan program tersebut. Karena itu, reorientasi terhadap strategi pembangunan masyarakat adalah keniscayaan. Kemunculannya lebih mengedepankan partisipasi dan pemberdayaan masyarakat sebagai strategi dalam pembangunan masyarakat. Untuk itu, diperlukan seperangkat teknik-teknik yang dapat menciptakan kondisi adanya keberdayaan masyarakat melalui proses pemberdayaan masyarakat secara partisipatif (Hikmat, 2006). 
Pemberdayaan dan partisipasi merupakan hal yang menjadi pusat perhatian dalam proses pembangunan belakangan ini di berbagai negara. Kemiskinan yang terus melanda dan menggerus kehidupan umat manusia akibat resesi internasional yang terus bergulir dan proses restrukturisasi, agen-agen nasionalinternasional, serta negara-negara setempat menunjukkan perhatian yang sangat besar terhadap strategi partisipasi masyarakat sebagai sarana percepatan proses pembangunan. Karena itu perlu ditekankan peningkatan tentang pentingnya pendekatan alternatif berupa pendekatan pembangunan yang diawali oleh proses pemberdayaan masyarakat lokal (Craig dan Mayo, 1995).

Pemberdayaan dan partisipasi merupakan strategi yang sangat potensial dalam rangka meningkatkan ekonomi, sosial dan transformasi budaya. Proses ini, pada akhirnya, akan dapat menciptakan pembangunan yang lebih berpusat pada rakyat. Salah satu agen internasional, Bank Dunia misalnya, percaya bahwa partisipasi masyarakat di negara dunia ketiga merupakan sarana efektif untuk menjangkau masyarakat termiskin melalui upaya pembangkitan semangat hidup untuk dapat menolong diri sendiri (Hikmat, 2006). Dalam hal ini cara terbaik untuk mengatasi masalah pembangunan adalah membiarkan semangat wiraswasta tumbuh dalam kehidupan masyarakat berani mengambil resiko, berani bersaing, menumbuhkan semangat untuk bersaing, dan menemukan hal-hal baru (inovasi) melalui partisipasi masyarakat. Strategi pembangunan meletakkan paartisipasi masyarakat sebagai fokus isu sentral pembangunan saat ini. Partisipasi masyarakat di negara-negara dunia ketiga merupakan strategi efektif untuk mengatasi masalah urbanisasi dan industrialisasi (Craig dan Mayo, 1995).

Sementara itu, strategi pemberdayaan meletakkan partisipasi aktif masyarakat ke dalam efektivitas, efisiensi, daan sikap kemandirian. Secara khusus, pemberdayaan dilaksanakan melalui kegiatan kerja sama dengan para sukarelawan, bukan bersumber dari pemerintah, tetapi dari LSM, termasuk organisasi dan pergerakan masyarakat (Hikmat, 2006).

Dikatakan juga bahwa partisipasi masyarakat melalui LSM, saat ini merupakan kunci partisipasi efektif untuk mengatasi masalah kemiskinan. Dengan cara ini, masyarakat kecil (kelompok grassroot) dapat memperoleh keadilan, hak asasi manusia, dan demokrasi. Kini, pemberdayaan masyarakat miskin sudah menjadi slogan umum. Dalam bidang pembangunan dan partisipasi masyarakat, 
pemberdayaan merupakan hal penting bagi negara-negara yang belum berkembang dan miskin di bagian Utara dan Selatan. (Hikmat, 2006) mengemukakan pula bahwa partisipasi masyarakat dalam melaksanakan gerakan pembangunan harus selalu di dorong dan ditumbuhkembangkan secara bertahap, mantap dan berkelanjutan. Jiwa partisipasi masyarakat adalah semangat solidaritas sosial, yaitu hubungan sosial yang selalu didasarkan pada perasaan moral, kepercayaan dan cita-cita bersama. Karena itu seluruh warga masyarakat harus selalu bekerjasama, bahu membahu, saling membantu dan mempunyai komitmen moral dan sosial yang tinggi dalam masyarakat. Sementara itu pendapat lain yang menyatakan tentang political will pemerintah yang juga harus tuntas dalam menangani kemiskinan masyarakat pantai (termasuk nelayan), termasuk pembinaan keluarga nelayan (anak dan isteri). Penanganan yang dilakukan melalui pendekatan partisipasif dapat membangkitkan peran kelompok masyarakat nelayan sehingga kelompok tersebut menjadi mandiri dan harmonis terhadap mitra usaha (lembaga ekonomi dan keuangan) dan dapat terwujudnya kesejahteraan masyarakat pesisir yang kemudian menyumbangkan potensi pendapatan negara dan dapat disejajarkan dengan sektor perekonomian yang lainnya.
Di dalam mencari jawaban penelitian ini, peneliti menggunakan teori yang di sampaikan oleh Suhendra, yaitu sebagai Berikut : Menyatakan bahwa terdapat metode partisipatori assessment (MPA) yang terdiri dari 4 langkah (Suhendra, 2006) :

1. Menemukan Masalah

a. Masalah Individu, kelompok, dan masyarakat yang dihadapi

b. Klasifikasi kesejahteraan masyarakat setelah pelaksanaan pemberdayaan

2. Menemukan dan mengenali potensi-potensi yang dimiliki

a. Adanya sarana dan prasarana

b. Adanya pelayanan yang baik dari pemerintah swasta maupun lsm dalam kegiatan pemberdayaan usaha.

3. Mengenali masalahan dan potensi

a. Mencari penyebab timbulnya masalah dalam pemberdayaan

b. Mencari faktor pendukung dan faktor penghambat dalam kegiatan pemberdayaan.

4. Memiliki solusi pemecahan masalah

a. Memberikan pelatihan

b. Memberikan program kemitraan

c. Memberikan pembinaan

d. Memberikan pengawasan 
Dimana peneliti berasumsi dengan teori tersebut akan memudahkan peneliti untuk menemukan sebuah jawaban penelitian, walaupun memang diawal disampaikan bahwasannya konsepan pemberdayaan yang ada sudah dijelaskan, namun teori ini hanya mempermudah peneliti didalam mencari sebuah jawaban penelitian. Namun dari ke 4 poin tersebut di atas peneliti hanya menggunakan 3 poin saja, karena poin terakhir (poin ke 4) peneliti simpan sebagai bahan untuk melakukan penelitian selanjutnya, artinya penelitian ini hanya baru sebatas mencari tahu sejauh mana proses pemberdayaan yang dilakukan ( ada atau tidak) dan juga untuk melihat apa saja faktor-faktor yang membuat pemberdayaan ini berjalan atau tidak berjalan. Karena peneliti berasumsi bahwasannya ketika proses pemberdayaan ini tidak berjalan dan dapat ditemukan faktor penghambatnya, maka dengan adanya pemenitian ini diharapkan dicarikan sebuah solusi untuk menjadikan disain pemberdayaan yang baik dilakukan diwilayah ini.

\section{METODE PENELITIAN}

\section{Tipe Penelitian.}

Tipe penelitian yang digunakan dalam penelitian ini dengan pendekatan kualitatif. Dengan rancangan desain seperti ini, calon peneliti berupaya untuk mengetahui dan memahami dengan mengumpulkan serta mengklasifikasikan data dan informasi secara mendalam mengenai proses penyampaian informasi.

Kedalaman data dan informasi tersebut kemudian digunakan untuk menganalisa, menginterpretasi dan menjelaskan fenomena dan makna dari realitas tentang transformasi komunikasi proses pemberdayaan yang dilakukan oleh Lembaga Pemberdayaan Msayarakat Desa kepada Nelayan. Oleh karenanya, ada beberapa langkah yang ditempuh yakni: 1) mengidentifikasi sumber informasi dalam hal ini BPD guna menemukan topik dan rumusan masalah. 2) Field work (kerja lapangan) yang meliputi kegiatan mencatat, mengamati, mendengarkan, mengumpulkan bahan dan menangkap semua fenomena, data dan informasitentang kasus yang diteliti. 3) menginterpretasi data dan informasi yang diperoleh serta hasil observasi. 4) Memaparkan hasil studi dalam bentuk laporan atau karya ilmiah (Salim, 2006).

Dalam menunjang penjaringan informasi, peneliti menjadikan setiap pihak yang dapat memberikan informasi dan data sebagai informan. Dalam rancangan penelitian, informan yang akan dipilih dan telah diwawancarai dalam penelitian ini adalah orang yang dipandang memiliki akses informasi yang terdiri dari tokohtokoh masyarakat, Nelayan, Pemerintah 
Desa (BPD) dan Kecamatan, Lembaga Swadaya Masyarakat, dan lembagalembaga lain yang terkait dengan penelitian ini.

\section{Metode Pengumpulan Data}

Model penelitian yang digunakan dalam penelitian ini adalah dengan menggunakan metode deskriptif dengan pendekatan kualitatif. Semua data yang dikumpulkan dapat memungkinkan menjadi sebuah jawaban atas apa yang dipertanyakan didalam penelitian (Moloeng, lelexy 2007). mendefinisikan penelitian kualitatif adalah : "penelitian yang bermaksud untuk memahami fenomena tentang apa yang dialami oleh subjek penelitian, misalnya perilaku, persepsi, motivasi, tindakan-tindakan dan lain-lain". Dan dengan cara deskrifsi dalam bentuk kata-kata dan bahasa, pada suatu konteks khusus yang alamiah dengan memanfaatkan berbagai metode ilmiah. Didalam penelitian ini meliputi 3 (tiga) hal dalam mengumpulkan data dan informasi yang dapat menjelaskan permasalahan penelitian. Ketiga teknik tersebut adalah :

1. Wawancara mendalam

Teknik ini digunakan untuk memperoleh data dan informasi sebanyak mungkin melalui tanyajawab (dialog) dengan para informan yang memiliki akses informasi. Pertanyaan yang akan digunakan pun bersifat terbuka, artinya jawaban atas sebuah pertanyaan dapat diikuti dengan pertanyaan turunan lainnya guna memperdalam fokus penelitian. Wawancara dengan informan pun dilakukan secara informal dengan tujuan agar sang informan tidak kaku sehingga dapat memberikan data dan informasi sebanyak mungkin mengenai kasus yang mereka ketahui, alami dan rasakan.

\section{Pengamatan (observation)}

Dalam penelitian ini, juga akan dilakukan kegiatan atau aktifitas pengamatan secara langsung wilayah terhadap rangkaian aktifitas kehidupan para pelajar dan mahsiswa di dalam asrama atau pemondokan. Observasi ini menjadi penting bagi Peneliti karena data dan informasi yang diperoleh dari informan tidak semuanya dapat menjawab pertanyaan penelitian. Selain itu, kemungkinan subyektivitas dari informan selalu ada sehingga dibutuhkan kejelian pengamatan untuk membantu menjawab pertanyaan penelitian. 
3. Studi dokumentasi dan kepustakaan

Selain itu, calon peneliti juga akan menjaring data dan informasi dari beberapa dokumen dan literatur tentang obyek penelitian. Dokumen dan literatur dimaksud berupa laporan-laporan Pemerintah Daerah, dokumen Sikon Kantrantibmas dari Kepolisian setempat, dokumen lainnya termasuk koran, jurnal dan catatan calon peneliti.

\section{Sumber Data}

Sumber data dalam penelitian ini adalah :

1. Sumber data utama diperoleh melalui wawancara dengan informan dan pengamatan langsung di lapangan.

2. Sumber data tambahan diperoleh dengan mempelajari bahan-bahan tertulis yakni beberapa dokumen yang berkaitan dengan masalah penelitian ini (Moloeng, lelexy, 2007).

\section{Teknik Pengolahan Data}

Sehubungan dengan pendekatan yang digunakan dalam penelitian ini yakni pendekatan kualitatif, maka dalam menganalisis data, peneliti tidak menggunakan uji statistik melainkan uji non statistik. Apabila kemudian terdapat data-data yang bersifat kuantitatif, maka hal tersebut sesungguhnya hanya digunakan untuk mempermudah analisa dan penafsiran peneliti untuk menjawab pertanyaan penelitian.

Berangkat dari argumen tersebut maka ada 3 (tiga) model analisis data yang akan digunakan yakni :

1. Reduksi data yaitu pemilihan, penyederhanaan data, penafsiran, pengabstrakan dan transformasi data.

2. Penyajian data yaitu penyusunan kembali data dan informasi yang telah diperoleh kedalam suatu bentuk yang lebih sederhana.

3. Penarikan kesimpulan yaitu penyusunan kesimpulan dari hasil analisa sebelumnya yang disesuaikan dengan pertanyaan penelitian.

\section{Lokasi Penelitian.}

Lokasi yang akan peneliti pilih sebagai tempat penelitian adalah Lembaga Pemberdayaan Msayarakat Desa Blanakan, Kecamatan Blanakan, Kabupaten Subang, Provinsi Jawa Barat.

\section{Populasi dan Sampling}

Populasi dalam penelitian atau kajian ini adalah Para Nelayan Dan Lembaga Pemberdayaan Msayarakat Desa Blanakan, dengan teknik pengambilan 
sampel yang dilakukan secara purposive sampling. Artinya, informan yang akan dijadikan sampel tergantung pada tujuan penelitian, adapun unit analisis atau informan dalam kajian atau penelitian ini terdiri dari:

1. Elemen Pemerintahan Desa, yang dalam hal ini adalah Lembaga Pemberdayaan Msayarakat Desa Blanakan.

2. Elemen Masyarakat, yang meliputi Nelayan, Tokoh Masyarakat, Tokoh Agama, Tokoh Pemuda, dan berbagai organisasi yang bergerak di bidang Perikanan, dll).

Penentuan informan atau responden dari kedua elemen tersebut tidak ditentukan secara spesifik, melainkan dilakukan Snowbowling, sehingga diharapkan diperoleh data seakurat mungkin. Namun didalam proses pencarian data melalui wawancara ini akan ditentuka jumlah inforam, diantaranya adalah Pemerintah desa (Kepala desa dan ketua BPD), 15 Orang nelayan yang diambil dari jumlah keseluruhan anggota nelayan 120 orang (KUD Mina Fajar Sidik Blanakan, 2013), yang mana 20 orang terasuk kedalam nelayan pemilik perahu dan sisanya nelayan buruh dan yang dijadikan sebagai calon informan dalam penelitian ini adalah 3 orang nelayan pemilik perahu dan 12 orang nelayan buruh. 5 orang yang bergerak dibidang kelautan (pengurus Koperasi dan para tokoh masyarakat). Namun dari jumlah informan yang akan dijadikan sebagai objek penelitian ini tidak menutup kemungkinan akan bertambah, hal ini lebih dikarenakan untuk menyempurnakan datadata yang ingin di cari dalam hal proses pemberdayaan yang dilakukan oleh pemerintah (BPD) didalam proses peningkatan tarap perekonomian masyarakat pesisir, dalam hal ini masyarakat nelayan. Adapun untuk pedoman wawancara tercantum dalam lampiran 2. 


\section{Diagram Tahapan Penelitian}

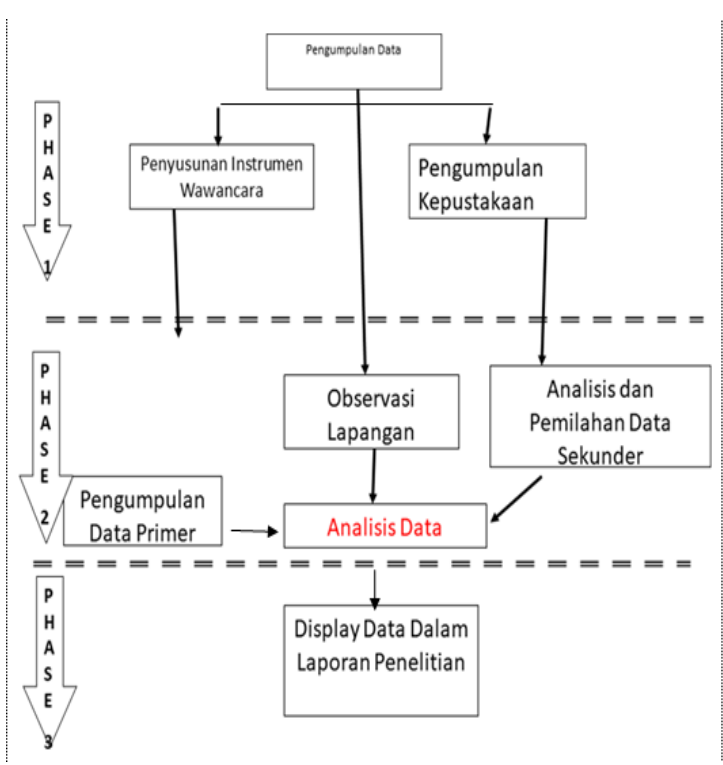

\section{Jadwal Pelaksanaan}

Jadwal pelaksanaan penelitian ini ditetapkan selama 360 ( tiga ratus enam puluh ) hari kerja atau kurang lebih selama 6 ( Enam ) bulan, dengan tahapan dan rincian kegiatan sebagai berikut :

\begin{tabular}{|c|c|c|c|c|c|c|c|}
\hline \multicolumn{8}{|c|}{ Tabel 3.1 Jadwal Penelitian } \\
\hline \begin{tabular}{l|l}
$N$ \\
0
\end{tabular} & Kegiatan & $\begin{array}{c}\text { Bln } \\
1\end{array}$ & $\begin{array}{c}\text { Bln } \\
2\end{array}$ & $\begin{array}{c}\text { Bln } \\
3\end{array}$ & $\begin{array}{c}\text { Bln } \\
4\end{array}$ & $\begin{array}{c}\text { Bln } \\
5\end{array}$ & $\begin{array}{c}\text { Bln } \\
6\end{array}$ \\
\hline \multirow{5}{*}{1} & Pra Penelitian & & & & & & \\
\hline & $\begin{array}{l}\text { Pengumpulan Studi } \\
\text { litelatur }\end{array}$ & & & & & & \\
\hline & Diskusi dengan pakar & & & & & & \\
\hline & $\begin{array}{l}\text { Penyusunan Tim } \\
\text { Peneliti }\end{array}$ & & & & & & \\
\hline & $\begin{array}{l}\text { Konsolidasi Tim } \\
\text { Peneliti }\end{array}$ & & & & & & \\
\hline \multirow[t]{4}{*}{2} & Persiapan Penelitian & & & & & & \\
\hline & Penyusunan Proposal & & & & & & \\
\hline & $\begin{array}{l}\text { Perancangan instrument } \\
\text { penelitian }\end{array}$ & & & & & & \\
\hline & $\begin{array}{l}\text { Pengurusan Perijian } \\
\text { Penelitian }\end{array}$ & & & & & & \\
\hline \multirow[t]{5}{*}{3} & $\begin{array}{l}\text { Pelaksanaan } \\
\text { Penelitian }\end{array}$ & & & & & & \\
\hline & $\begin{array}{l}\text { Pengumpulan Data } \\
\text { Primer }\end{array}$ & & & & & & \\
\hline & $\begin{array}{l}\text { Pengumpulan Data } \\
\text { Sekunder }\end{array}$ & & & & & & \\
\hline & $\begin{array}{l}\text { Pengolahan dan } \\
\text { Anslisis Data Primer }\end{array}$ & & & & & & \\
\hline & $\begin{array}{l}\text { Pengolahan dan } \\
\text { Analisis Data Sekunder }\end{array}$ & & & & & & \\
\hline \multirow[t]{3}{*}{4} & $\begin{array}{l}\text { Penyelesaian } \\
\text { Penelitian }\end{array}$ & & & & & & \\
\hline & $\begin{array}{l}\text { Penyusunan Laporan } \\
\text { Akhir }\end{array}$ & & & & & & \\
\hline & $\begin{array}{l}\text { Penggandaan dan } \\
\text { Pencetakan Laporan }\end{array}$ & & & & & & \\
\hline \multirow[t]{2}{*}{5} & Publikasi & & & & & & \\
\hline & $\begin{array}{l}\text { Penyusunan naskah } \\
\text { publikasi di Jurnal }\end{array}$ & & & & & & \\
\hline
\end{tabular}

\section{HASIL PENELITIAN DAN}

\section{PEMBAHASAN}

\section{Hasil Penelitian}

\subsection{Gambaran umum Desa Blanakan}

\subsubsection{Keadaan Geografis}

Desa Blanakan adalah satu dari 9 desa yang terletak di kecamatan balanakan kabupaten Subang, dimana desa ini memiliki potensi kelautan dan perikanan yang sangat baik dibandingkan dengan 8 desa lainnya. Dimana di desa ini terdapat 
sebuah pemukiman nelayan dan lahan pertambakan yang sangat luas. Tidak semua masyarakat di desa ini berprofesi sebagai nelayan, karena didaerah ini selain lahan tambah yang luas desa ini juga memiliki lahan pertanian yang juga sangat luas. Desa Blanakan secara administrative berbatasan memiliki perbatasan sebagai berikut :

- Sebelah Utara : : Laut Jawa

Sebelah Selatan : Desa

Ciasem Baru ( Kec. Ciasem)

* Sebelah Timur : Desa

Langgensari (Kec. Blanakan)

Sebelah Barat : Desa

Jayamukti (Kec. Blanakan)

Letak wilayah yang berbatasan langsung dengan laut jawa memberikan sebuah keuntungan bagi penduduk desa blanakan untuk dapat memanfaatkan potensi kelautan didalam membantu meningkatakan kehidupan khususnya dalam bidang perekonomian, dimana wilayah indonesia yang merupakan negara kedua yang memiliki garis pantai terpanjang didunia setelah kanada yaitu $81.000 \mathrm{Km}$ memiliki potensi kelautan yang dapat dimanfaatkan bagi penduduk yang berada di wilayah pantai tersebut. Luas wilayah desa Blanakan yaitu sekitar : 980,460 Ha, dimana secara penggunaannya dibagi kedalam : luas tanah pemukiman $156,329 \mathrm{Ha}$, luas tanah persawahan 424,065 Ha, luas perkantoran
3,564 Ha dan Luas Tanah Tambak sekitar $331 \mathrm{Ha}$.

\subsubsection{Keadaan Demografi}

Jumlah penduduk desa Blanakan berdasarkan data desa Blanakan tahun 2014 adalah 12.054 Orang (Pendataan Profil Desa/Kelurahan Desa Blanakan,2014). Terdiri dari jenis kelamin laki-laki 6.584 orang dan perempuan 5.470 orang. Kemudian untuk jumlah kepala keluarga di desa blanakan adalah sebanyak 3.600 kepala keluarga. Kepadatan penduduk di desa blanakan rata-rata 9.00/ $\mathrm{Km}$. dari total jumlah penduduk yang 11.300 orang sekitar 3,176 (KUD Mina Fajar Sidik Blanakan, 2013) adalah keluarga nelayan dan 315 penduduk berprofesi sebagai nelayan (Anggota Aktif KUD Mina Fajar Sidik Blanakan, 2014).

Berdasarkan data yang telah di peroleh dari hasil laporan pendataan profil desa blanakan tahun 2014 untuk jumlah penduduk berdasarkan usia dan kesejahteraan dapat dijelaskan pada uraian berikuit ini :

\subsubsection{Penduduk berdasarkan Usia dan kesejahteraan \\ Data tentang penduduk} berdasarkan usia dan kesejahteraan ini erat hubungannya dengan tenaga kerja produktif. komposisi penduduk berdasarkan usia merupakan komponen penting karena dapat mengetahui karakteristik penduduk dan angka beban 
kerja, selain itu data komposisi penduduk berdasarkan usia dapat pula dimanfaatkan untuk analisis jumlah angkatan kerja pada daerah tertentu atau dapat juga diketahui fasilitas kesehatan dan pendidikan yang diperlukan di suatu daerah.

Penduduk daerah penelitian di desa blanakan berdasarkan usia dan kesejahteraan dapat dilihat dari table di bawah ini :

\begin{tabular}{|c|c|}
\hline \multicolumn{2}{|l|}{$\begin{array}{c}\text { Tabel } 4.1 \\
\text { Penduduk berdasarkan Usia dan kesejahteraan }\end{array}$} \\
\hline Ekonomi Masyarakat & $\begin{array}{c}\text { Jumlah } \\
\text { Org }\end{array}$ \\
\hline $\begin{array}{l}\text { A. Pengangguran } \\
\text { 1. Jml angkatan Kerja ( Penduduk usia } 18-45 \text { th) } \\
\text { 2. Jml penduduk usia } 18-56 \text { th yang masih sekolah dan tidak } \\
\text { bekerja. } \\
\text { 3. Jml penduduk usia } 18-56 \text { th yang menjadi ibu rumah tangga. } \\
\text { 4. Jlm penduduk usia } 18-56 \text { th yang bekerja penuh. } \\
\text { 5. Jlm penduduk usia } 18-56 \text { th yang bekerja tidak penuh. } \\
\text { 6. Jlm penduduk usia } 18-56 \text { th yang cacat dan tidak bekerja. } \\
\text { 7. Jlm penduduk usia } 18-56 \text { th yang cacat dan bekerja. }\end{array}$ & $\begin{array}{l}3.727 \\
2.535 \\
2.536 \\
2.537 \\
2.538\end{array}$ \\
\hline $\begin{array}{l}\text { B. Kesejahteraan Keluarga } \\
\text { 1. Jumlah keluarga Prasejahtera. } \\
\text { 2. Jumlah keluarga Sejahtera } 1 . \\
\text { 3. Jumlah keluarga Sejahtera } 2 . \\
\text { 4. Jumlah keluarga Sejahtera } 3 \text {. } \\
\text { 5. Jumlah keluarga Sejahtera } 3 \text { Plus } \\
\text { 6. Total Jumlah Kepala keluarga. }\end{array}$ & $\begin{array}{c}1.329 \\
853 \\
792 \\
461 \\
89 \\
4.403 \\
\end{array}$ \\
\hline $\begin{array}{l}\text { Sumber : Data Pendataan Profil Desa/ Kelurahan, Desa Balanak } \\
\text { Kabupaten Subang Jabar. }\end{array}$ & \\
\hline
\end{tabular}

Dari tebel jumlah penduduk berdasarkan usia dan kesejahteraan penduduk, dapat dikatakan desa blanakan sebagai desa yang kurang produktif bekerja. Ini dapat dilihat dari table diatas, dimana ibu rumahtangga mendominasi. namun iburumah tangga di desa ini memiliki kegiatan atau bekerja tidak penuh waktu, artinya ibu-ibu di desa ini juga ikut didalam kegiatan perekonomian walaupun tidak penuh (Pagi sampai Siang hari atau setengah hari).

\subsubsection{Keadaan Sosial Ekonomi Desa Blanakan}

Keadaan sosial ekonomi desa blanakan dapat dilihat dari jumlah penduduk menurut mata pencaharian penduduk, dimana ini sangat erat hubungannya dengan lingkungan dimana dia tinggal. Lingkungan sangat mempengaruhi tingkat mata pencahariandi suatu tempat, dimana jika lingkungan pedesaan maka mata pencaharian yang akan dominan di wilayah ini adalah pertanian dan perikanan (jika wilayah pedesaan pesisir). Komposisi penduduk berdasarkan mata pencaharian di desa Blanakan dapat dilihat pada table berikut ini

\begin{tabular}{|c|c|c|c|}
\hline \multicolumn{4}{|c|}{$\begin{array}{c}\text { Tabel } 4.2 \\
\text { Penduduk berdasarkan Mata Pencaharian } \\
\end{array}$} \\
\hline No & Jenis Pekerjaan & Laki-Laki & Perempuan \\
\hline 1. & Petani & 2.468 & 2.004 \\
\hline 2. & Buruh Tani & 2.319 & 1.101 \\
\hline 3. & Buruh Migran & 217 & 313 \\
\hline 4. & Pegawai Negeri Sipil & 65 & 52 \\
\hline 5. & Pengerajin Industri Rumah Tangga & 53 & 69 \\
\hline 6. & Pedagang Keliling & 65 & 94 \\
\hline 7. & Peternak & 71 & 3 \\
\hline 8. & Perikanan & 265 & 159 \\
\hline 9. & Nelayan & 315 & - \\
\hline 10. & Montir & 17 & - \\
\hline 11. & Dokter & 3 & - \\
\hline 12. & Bidan & 0 & 9 \\
\hline 13. & Perawat & 5 & 5 \\
\hline 14. & Pembantu Rumah Tanggg & 59 & 235 \\
\hline 15. & TNI/ POLRI & 6 & - \\
\hline 16. & Pensiunan PNS / TNI / POLRI & 15 & - \\
\hline 17. & Pengusaha Kecil dan menengah & 193 & 173 \\
\hline 18. & Pengacara & 2 & - \\
\hline 19. & Dukun Terlatih & 2 & 1 \\
\hline 20. & Jasa Pengobatan Alternatif & 3 & - \\
\hline 21. & Dosen Swasta & 2 & - \\
\hline 22. & Pengusaha Besar & 2 & - \\
\hline 23. & Seniman/Artis & 9 & 3 \\
\hline 24. & Karyawan Perusahaan Swasta & 72 & 75 \\
\hline 25. & Karyawan Perusahaan Pemerintah & 35 & 39 \\
\hline 26. & Lain-Lain & 323 & 317 \\
\hline & Jumlah & 6.584 & $\mathbf{5 . 4 7 0}$ \\
\hline & Jumlah Total Penduduk & & 54 \\
\hline
\end{tabular}




\subsubsection{Keadaan Sosial Budaya Desa Blanakan}

Keadaan sosial budaya desa blanakan dapat dilihat dari jumlah penduduk berdasarkan pendidikan, pemelukan agama, dan penduduk menurut kesehatan. Pendidikan merupakan hal terpenting didalam sebuah proses pembangunan di suatu wilayah, karena tingkat kemandirian suatu wilayah juga dapat dilihat dari tingkat pendidikan masyarakatnya. Pendidikan juga memiliki peranan penting dan strategi didalam meningkatkan tarap kehidupan perekonomian dan didalam meningkatkan sumber daya manusia suatu masyarakat disuatu tempat.

Pendidikan dijadikan salah satu pertimbangan penting didalam suatu institusu yang mampu menyediakan tenaga kerja yang sesauai dengan keahlian dan bahkan mempersiapkan masyarakat dengan keterampilan-keterampilan yang di peroleh sehingga mampu membuka dan memperluas lapangan pekerjaan, atau bahkan dapat menumbuhkembangkan potensi yang sudah dimiliki suatu wilayah menjadi sebuah proses modernisasi.

Komposisi penduduk berdasarkan tingkat pendidikan di desa Blanakan ini dapat dilihat pada table 4.3 penduduk berdasarkan tingkat pendidikan.

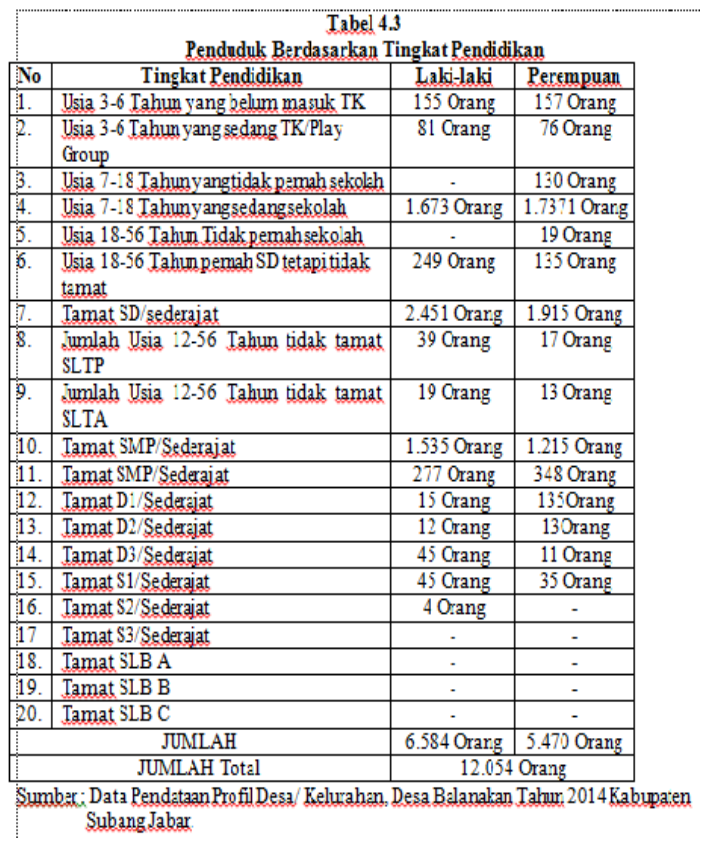

Dalam hal pemelukan agama, warga desa Blanakan memeluk agama Islam. Artinya secara kepercayaan atau agama warga Desa Blanakan tidak beragam atau hanya ada pemeluk agama islam saja. Sedangkan dalam hal Prasarana kesehatan desa blanakan dapat dikatakan sudah memadai, dimana didesa ini terdapat Puskesmas dan klinik. Hal ini di harapkan mampu mengingkatkan kesehatan masyarakat di desa Blanakan. Selain Puskesmas dan klinik ada beberapa pasilitas kesehatan yang lain yang terdapat di desa Blanakan, hal ini dapat dilihat dalam table di bawah ini : 


\begin{tabular}{|c|c|c|c|c|}
\hline \multicolumn{5}{|c|}{$\begin{array}{c}\text { Tabel 4.4 } \\
\text { Sarana dan Prasarana Kesehatan Desa Blanakan }\end{array}$} \\
\hline No & Saraza Kesehatan & Jumlah & \begin{tabular}{|l} 
Prasarana \\
\end{tabular} & Unit \\
\hline 1. & Dokter Umum & 2 & \begin{tabular}{|l|} 
Puskesmas \\
\end{tabular} & 1 \\
\hline 2. & Dukuz Bersalin Terlatih & 2 & $\begin{array}{l}\text { Poliklinik/Balai } \\
\text { Pengobatan/Polindes }\end{array}$ & 2 \\
\hline 3. & Bidan & 6 & Apotik & 4 \\
\hline i. & Perawat & 2 & Posyandu & 7 \\
\hline$\overline{5}$. & Dukuב Pengobatan Alternatif & 1 & Toko Obat & 2 \\
\hline \%. & Dokter Praktek & 1 & $\begin{array}{l}\text { Balai Pengobatan } \\
\text { Masyarakat } \\
\text { Yayasan/Swasta } \\
\end{array}$ & 2 \\
\hline 7. & Tabib & $\cdot$ & Rumah Bersalin & 2 \\
\hline 3. & Dokter Gigi & $\cdot$ & $\begin{array}{l}\text { Balai kesehatan ibu dan } \\
\text { anak }\end{array}$ & 1 \\
\hline
\end{tabular}

\section{Pembahasan}

Dalam sub bab ini peneliti akan mengemukakan hasil penelitian yang dilakukan dengan tema Pemberdayaan masyarakat pesisir (nelayan) desa blanakan, kecamatan blanakan, kabupaten subang jawa barat. Berdasarkan permasalahan yang telah dikemukakan dalam bab 1 dimana peneliti ingin mengetahui sejauh mana peranan lembaga pemberdayaan masyarakat desa, desa blanakan didalam memberdayakan masyarakatnya (khususnya Nelayan).

Dalam hal ini peneliti membagi dua informan, dimana informan dari pihak desa (LPMDes ataupun pihak desa) dengan masyarakat nelayan. Hal ini dilakukan agar penelitian ini dapat berkembang dengan baik dan dapat memaksimalkan data-data yang dihasilkan. Sehingga diharapkan mendapatkan hasil penelitian yang lebih maksimal. Adapun dinemsi dan indikator yang digunakan peneliti sebagai tolak ukur dalam pemberdayaan masyarakat pesisir (nelayan) di desa Blanakan kabupaten Subang oleh pemerintah desa, menurut (Suhendra, 2006), yaitu sebagai Berikut :

Menyatakan bahwa terdapat metode partisipatori assessment (MPA) yang terdiri dari 4 langkah :

\section{Menemukan Masalah}

a. Masalah Individu, kelompok, dan masyarakat yang dihadapi,

b. Klasifikasi kesejahteraan masyarakat setelah pelaksanaan pemberdayaan

2. Menemukan dan mengenali potensi-potensi yang dimiliki
a. Adanya sarana dan prasarana
b. Adanya pelayanan yang baik
dari pemerintah swasta maupun lsm dalam kegiatan pemberdayaan usaha.

3. Mengenali masalahan dan potensi
a. Mencari penyebab timbulnya masalah dalam pemberdayaan,
b. Mencari faktor pendukung dan faktor penghambat dalam kegiatan pemberdayaan.
4. Memiliki solusi pemecahan masalah
a. Memberikan pelatihan
b. Memberikan program kemitraan
c. Memberikan pembinaan
d. Memberikan pengawasan 


\subsection{Menemukan Masalah}

\subsubsection{Masalah Individu,}

kelompok, dan masyarakat yang dihadapi.

Dari hasil wawancara yang dilakukan peneliti mendapatkan 6 informan yang pada hasilnya semua informan hampir mendekati kesimpulan yang sama walaupun dalam tanggapan yang berbeda-beda. berikut adalah informan yang sudah diwawancarai oleh peneliti, sebagai berikut :

1. Ketua Lembaga Peberdayaan masyarakat Desa, desa Blanakan kabupaten Subang bpk. Toto Sugiarto SH.

“ Tidak ada masalah. Karena Dalam hal pemberdayaan masyarakat nelayan semuanya sudah dilakukan oleh koperasi, Jadi kami harus melakukan apa lagi. Ini yang kami sebut di awal kami tidak bermasalah dalam hal pemberdayaan masyarakat nelayan. “

2. Sekertaris Desa Blanakan Bpk. Heri Susanto SH.

“ Kalau permasalahan tidak ada sebenarnya, namun dalam prakteknya adanya tumpang tindih kewenangan yang dimiliki antara pemerintah desa dengan koperasi.
Dimana koperasi dibawah dinas kelautan dan perikanan berkoordinasi langsung kesana, namun ketika ada sebuah permasalahan yang berkaitan tentang pemberdayaan ataupun permasalahan lain yang berkaitan dengan nelayan ataupun yang lainnya ini jelas adalah kewenangan dari pemerintah desa. Dengan kata lain koperasi."

3. Sekertaris Koperasi Unit Desa Mina Fajar Sidik desa Blanakan Bpk. Dasam.

“ Permasalahan yang berarti didalam pengelolaan kelautan dan anggota koperasi (nelayan) tidak mengalami permasalahan yang berarti, kalau pun ada saat ini hanya permasalahan sekitar alat tangkap nelayan saja, dikarenakan masih adanya nelayan yang memakai alat tangkap yang dilarang oleh pemerintah lewat kementrian kelautan, namun perlahan tapi pasti hal ini juga mulai kita perbaiki bersama melalui penyuluhan kepada para nelayan agar tidak menggunakan kembali alat tangkap yang dilarang oleh pemerintah."

4. Nelayan pemilik perahu, Bpk. Tarman. 
"Permasalahan yang dihadapi tidak ada, bagi kami nelayan permasalahan yang dihadapi hanya persoalan cuaca yang tidak menentu dengan hasil tangkapan yang semakin hari semakin menurun saja."

5. Nelayan Buruh, Bpk walim.

"Permasalahan yang di alami tidak ada, karena koperasi sudah memperlakukan kita dengan baik, baik dalam bidang keselamatan, maupun kesehatan. Walaupun kadang bantuan-bantuan dari pemerintah tidak pernah sampai kekami, hal ini dikarenakan kami bukanlah anggota koperasi."

6. Tokoh masyarakat bpk. H. Udin “ Tidak ada persoalan dengan keberadaan masyarakat nelayan di lingkungan ini, justru dengan adanya mereka kita sangat di untungkan dari sisi ekonomi. Namun mungkin yang menjadi permaikan kedepan adalah penataan kembali pemukiman nelayan tersebut, dimana bisa kita bedakan antara wilayah utara (pemukiman nelayan) dengan wilayah di selatan. Wilayah utara terkesan sangat kumuh sekali dibandingkan dengan wilayah selayan, hal ini seharusnya menjadi perhatian bersama. Walaupun kita ketahui bersama yang namanya pemukiman nelayan dimana-mana tidak jauh seperti itu. Namun alangkah baiknya pemukiman nelayan juga bersih dan layak untuk ditinggali."

Dari hasil wawancara di atas peneliti menyimpulkan ada beberapa permasalahan yang dihadapi dari setiap informan, dimana dari pihak pemerintah baik dari LPMDes maupun dari Desa sendiri yang menganggap tidak adanya singkronisai terhadap persoalanpersoalan yang dihadapi bersama, sehingga didalam penenganannya berjalan dengan caranya masingmasing didalam menghadapi persoalan nelayan. Hal ini dikarenakan adanya tumpang tindih kewenangan antara Pemerintah desa dengan dinas kelautan. Dimana peneliti melihat peran koperasi lebih besar didalam melayani masyarakat nelayan dibandingkan dengan pemerintah desa, hal ini dianggap wajar oleh pemerintah desa dimana kewenangan ini memang tanggungjawab dari ketua koperasi didalam mensejahterakan dan memberdayakan anggotanya. Namun hal lain yang terlupakan adalah masyarakat nelayan buruh, dimana nelayan buruh ini tidak terdaftar 
menjadi anggota koperasi. Dimana walaupun memang mereka mendapatkan layanan kesehatan dan keselamatan kerja dari koperasi layaknya anggota koperasi (nelayan pemilik perahu) namun mereka mengalami beberapa kesulitan, dimana tarap kehidupan perekonomian mereka tidak mengalami peningkatan.

Hal lain yang peneliti anggap menjadi sebuah persoalan adalah nelayan buruh ini menjadi golongan yang terlupakan, dimana koperasi lebih fokus kepada anggotanya karena memang ini adalah tugas dan fungsi dari koperasi itu sendiri, dan mengesampingkan persoalan dari nelayan buruh. Sedangkan dari LPMDes sendiri mereka tidak di perhatikan dengan baik, hal ini dapat dilihat dari 5 ruang lingkup kegiatan LPMDes (Pendataan Profil

Desa/Kelurahan

Desa

Blanakan,2014) 1.

Kemasyarakatan, 2. Pembangunan,

3. Pemuda dan olah raga, 4. Keagamaan, 5. Peranan wanita. Tidak ada program khusus untuk menangani persoalan yang dihadapi oleh masyarakat nelayan pada umumnya dan masyarakat nelayan buruh pada khususnnya. Dimana peneliti merlihat tidak adanya program pemberdayaan yang dilakukan pemerintah desa melalui LPMDes ini lebih kepada tumpang tindihnya kewenangan dan tidak adanya keseriusan pemerintah untuk menjadikan masyarakat nelayan ini sejajar dengan kehidupan dengan sector perekonomian lainnya.

\subsubsection{Klasifikasi kesejahteraan} masyarakat setelah pelaksanaan pemberdayaan.

1. Ketua Lembaga Peberdayaan masyarakat Desa, desa Blanakan kabupaten Subang bpk. Toto Sugiarto SH.

“ Terus terang kami dari LPMDes tidak pernah melakukan pemberdayaan secara langsung kepada masyarakat nelayan, hal ini kami hindari karena takut bertabrakan dengan kewenangan yang dimiliki oleh ketua koperasi, karena kalau kami melakukan hal ini dikhawatirkan tidak singkron dengan program-program yang sudah direncanakan oleh ketua koperasi beserta anggotaanggotanya. Mungkin kalau pun kami harus melakukan pemberdayaan sebatas pada masyarakat pengolah hasil tangkapan nelayan (Ikan asin, dan pengolahan abon ikan) dan hal ini 
pun kami fokuskan kepada ibuibunya saja, karena hal ini sangat susah untuk dilakukan oleh kaum lelaki. Jadi kalau ditanyakan tingkat kesejahteraan nelayan, jelas lebih sejahtera dibandingkan dengan masyarakat kelompok petani, dimana masyarakat memiliki jaminan kesehatan yang ditanggung oleh koperasi.“

2. Sekertaris Desa Blanakan Bpk. Heri Susanto SH.

“ Pemberdayaan masyarakat nelayan selalu kita lakukan, salah satunya mengirimkan perwakilan untuk mengikuti penyuluhan ataupun pelatihan baik di tingkat kabupaten ataupun tingkat provinsi. Namun persoalannya adalah orang-orang yang kami kirim notabene mereka bukanlah nelayan, atau dengan kata lain mereka masyarakat biasa yang bahkan tidak mengerti apa-apa dalam bidang kelautan kita kirimkan. Hal ini dilakukan karena sangat sulit sekali untuk mengirimkan mereka untuk mengikuti acara-acara yang seperti itu berbeda dengan petani, dimana para petani mau mengirimkan anggota kelompoknya untuk mengikuti acara-acara pelatihan ataupun penyuluhan yang kemudian ditularkan kepada anggota yang lainnya. Dan persoalan lain yang timbul adalah ketika kita mengirimkan anggota masyarakat untuk mengikuti acara tersebut dan melakukan penyuluhan kepada masayarakat nelayan seakan mereka acuh tiak acuh, mereka lebih memilih melaut dibandingkan menghadiri acaraacara seperti itu. Tapi kalau berbicara tingkat kesejahteraan tentu masyarakat nelayan sejahtera."

3. Sekertaris Koperasi Unit Desa Mina Fajar Sidik desa Blanakan Bpk. Dasam.

“ Kalau persoalan sejahtera atau tidak kami bingung menjawabnya, karena kami tidak punya indikator khusus untuk mengukur tingkat kesejahteraan nelayan, namun yang pasti hal-hal yang mengarah kepada kesejahteraan terus kami tingkatkan. Mulai dari tingkat pendidikan keluarga nelayan, kesehatan nelayan dan keluarganya sampai kepada peningkatan kuwalitas nelayan sendiri melalui penyuluhan dan pelatihan, yang bekerjasama dengan dinas perikanan dan kelautan. Saya kira hal itu sudah cukup menjawab pertanyaan sejauh mana 
kesejahteraan masyarakat nelayan, karena setiap tahun kita selalu meningkatkan mutu pelayanan kepada seluruh anggota."

4. Nelayan pemilik perahu, Bpk. Tarman.

“ Kesejahteraan kami sebagai anggota koperasi dapat dikatakan sudah baik, karena koperasi memberikan kami banyak sekali fasilitas yang membantu meringankan beban hidup kami. Mulai dari kesehatan, pendidikan sampai kepada pelatihan dan penyuluhan. Hal lain yang kami rasakan baik adalah, kami sebagai nelayan merasa terfasilitasi sekali dengan keberadaan KUD. Dimana kita tidak lagi harus memikirkan kemana kami akan menjual hasil tangkapan kami, dan yang terpenting adalah KUD Mina Fajar ini adalah salah satu koperasi terbaik yang ada diwilayah jawabarat, dimana disini hasil tangkapan kami yang dijual disini dihargai dengan baik dan tidak pernah di hutang. Itu sangat penting sekali, karena dibeberapa koperasi yang lain hasil tangkapan kami dihutang, tentunya hal ini akan menghambat perputaran perekonomian kami dan keluarga."

5. Nelayan Buruh, Bpk walim.
“Untuk kesejahteraan nelayan saya kira sudah baik, apa yang dilakukan oleh koperasi sudah lebih dari cukup, walaupun memang ada hal-hal yang lain seperti tidak tersalurkannya bantuan pemerintah kepada kami. Yah hal ini kami sadari karena memang kami tidak terdaftar sebagai anggota koperasi, sehingga bantuan pemerintah didasarkan kepada data keanggotaan."

6. Tokoh masyarakat bpk. H. Udin "Kesejahteraan masyarakat nelayan saya kira lebih baik dibandingkan dengan kesejahteraan masyarakat lainnya. kenapa saya bilang seperti itu, kebetulan saya salah satu pengurus gapoktan (kelompok tani), kami tidak memiliki jaminan kesehatan seperti yang dimiliki nelayan. Jadi kalau anggota kelompok kami sakit ya hanya bisa mendoakan saja, berbeda dengan nelayan mereka ditanggung biaya pengobatannya oleh koperasi."

Permasalahan kesejahteraan memang menjadi fokus utama didalam sebuah pemberdayaan, dimana hasil akhir yang ingin dicapai dari sebuah pemberdayaan adalah kesejahteraan. Dari hasil wawancara di atas memang menyimpulkan tingkat kesejahteraan 
masyarakat nelayan dapat dikategorikan baik, namun hal ini hanya dilakukan oleh koperasi terhadap para anggotanya saja. Atau dengan kata lain pemenuhan kesejahteraan itu tidak dilakukan oleh pemerintah. Kembali peneliti menyimpulkan hal ini terjadi karena adanya kurang koordinasi antara pemerintah desa dalam hal ini LPMDes dengan pihak koperasi, dimana pihak koperasi menjalankan tugas dan kewajibannya sesuai dengan fungsinya sebagai koperasi untuk mensejahterakan anggotanya, dan LPMDes tidak melakukan pemberdayaan karena takut melangkahi kewenangan yang dimiliki oleh ketua kolerasi dan dikhawatirkan pemberdayaan yang mereka lakukan berbenturan dengan program pemberdayaan yang dilakukan koperasi.

\subsection{Menemukan dan mengenali potensi- potensi yang dimiliki}

\subsubsection{Adanya sarana dan prasarana}

1. Ketua Lembaga Peberdayaan masyarakat Desa, desa Blanakan kabupaten Subang bpk. Toto Sugiarto SH.
"Kalau sarana dan prasarana kita sudah ada yah, mulai dari TPI (tempat penjualan ikan), tempat bersandar perahu, dan pernah dibuatkan perumahan khusus buat nelayan. Nah kembali setelah semuanya ada pengelolaan dan pemeliharaannya di lakukan oleh ketua koperasi karena kembali saya sampaikan itu adalah kewenangan dari koperasi.“

2. Sekertaris Desa Blanakan Bpk. Heri Susanto SH.

"Sarana dan prasarana sudah dapat dikatakan sudah memadai, walaupun memang tidak semua dibuat khusus untuk nelayan. Artinya sarana dan prasarana yang untuk kepentingan bersama kita buatkan dan sarana dan prasarana untuk menunjang kegiatan nelayan kita juga sudah ada, mulai dari TPI (tempat penjualan Ikan) sampai kepada sekolah yang dekat dengan permukiman mereka."

3. Sekertaris Koperasi Unit Desa Mina Fajar Sidik desa Blanakan Bpk. Dasam.

“ Bisa dilihat saja sarana dan prasarana untuk menunjang kegiatan nelayan sudah ada semuanya, namun untuk persoalan layak atau tidaknya kami kira semuanya sudah kami anggap 
layak. Mulai dari tempat penjualan ikan yang besar, kami memiliki pabrik es sendiri, pom solar sendiri, mobil ambulance sendiri. Dan semuanya kami mencoba untuk memenuhi standar yang diberikan pemerintah kepada kami selaku pengelola koperasi. Jadi kalau ditanyakan sarana dan prasarana yang dimiliki koperasi untuk kegiatan koperasi bisa dikatakan sudah baik dan sesuai."

4. Nelayan pemilik perahu, Bpk. Tarman.

" Semua sarana dan prasarana disini sudah sangat baik dibandingken dengan beberapa koperasi yang ada."

5. Nelayan Buruh, Bpk walim.

“ Dari beberapa TPI (tempat penjualanikan) yang pernah saya datangi, mungkin TPI ini yang dapat dikatakan memiliki standar sarana dan prasarana yang baik. Tidak hanya itu pelayanan yang diberikan juga sangat baik, contohnya setiap kami ada keluhan sakit dan melapor ke satpam maka kami langsung ditangani dan di sarankan untuk ke dokter yang sudah ditunjuk dan bekerjasama dengan koperasi. Jadi saya kira untuk sarana dan prasarana di koperasi ini sudah baik"
6. Tokoh masyarakat bpk. H. Udin

“ Sarana dan prasarana untuk nelayan dapat dikatakan baik, masalahnya semuanaya sudah tersedia dan dapat dipenuhi semuanya oleh sendiri. Dimana yang paling dibutuhkan adalah bahan bakar solar dan es buat pengawet hasil tangkapan agar tetap segar, itu semuanya sudah ada disini."

Sarana dan prasarana menjadi hal terpenting didalam sebuah pelayanan, dimana sarana dan prasarana dijadikan salah satu indikator terhadap baik dan buruknya sebuah pelayanan. Dalam penelitian ini peneliti melihat dan menyimpulkan hasil wawancara yang dilakukan menunjukan hal yang baik dalam hal sarana dan prasarana, dimana diwilayah ini sarana dan prasarana penunjang kegiatan nelayan sudah tersedia dengan baik. Diwilayah Blanakan memiliki Pabrik pengolahan es, dimana es ini banyak diperuntukan untuk mengawetkan es, baik ikan dari laut sampai ke tempat penjualan maupun dari tempat penjualan sampai di distribusuian kepada penjual-penjual. Selain itu tempat penjualan ikan (TPI) yang relatif 
bersih, tempat ini juga sudah menyediakan pom solar, memiliki mobil ambulance, tempat pendidikan yang dekat dengan pemukiman nelayan dan juga pasar yang juga tidak jauh dari permukiman mereka.

Dengan adanya sarana dan prasarana yang baik tersedia di lokasi ini tentu akan mempermudah kegiatan nelayan didalam menjalankan usaha, karena semua yang mereka butuhkan berada tidak jauh dari permukiman mereka.

2.2.2 Adanya pelayanan yang baik dari pemerintah, swasta maupun Ism dalam kegiatan pemberdayaan usaha.

1. Ketua Lembaga Peberdayaan masyarakat Desa, desa Blanakan kabupaten Subang bpk. Toto Sugiarto SH.

“ Semua pihak melakukan pelayanan yang baik didalam pemenuhan kebutuhan kearah kesejahteraan, tentunya dalam hal ini kembali saya sampaikan bahwasannya pemenuhuan kebutuhan tadi banyak dilakukan oleh koperasi. Mungkin yang menjadi pekerjaan rumah lembaga kami adalah bagaimana mengkonsep proses pemberdayaan yang baik untuk mendongkrak kualitas, baik SDM maupun sarana atau prasarana agar kelompok nelayan ini menjadi sektor yang juga dapat memberikan kontribusi besar bagi daerah. Tentunya ini harus dibicarakan bersama dengan ketua koperasi agar apa yang akan kita lakukan tidak bertabrakan dengan kewenangan yang dimilikinya."

2. Sekertaris Desa Blanakan Bpk. Heri Susanto SH.

“ Untuk persoalan dalam konsep pelayanan, kami dari pihak desa mungkin hanya sebatas secara administratif saja atau dengan kata lain prosesnya sama dengan masyarakat yang lain, tidak ada proses pelayanan yang istimewa."

3. Sekertaris Koperasi Unit Desa Mina Fajar Sidik desa Blanakan Bpk. Dasam.

“ Proses pelayanan yang baik selalu kita lakukan, baik untuk meningkatkan hasil tanggkapan sampai kepada pelayanan yang berkaitan dengan sarana dan prasana, dan yang paling penting buat kami adalah bagai mana caranya kita melayani dengan baik para nelayan ini agar mereka ketika pergi melaut tidak memiliki beban, artinya kesehatan dan persoalan 
yang para nelayan hadapi di darat sudah terselesaikan dan tidak terbawa sampai mereka melaut. Seperti di jelaskan di pertanyaan sebelumnya, bahwasannya pemenuhan sarana dan prasarana yang terus kami tingkatkan juga menjadi salah satu strategi kita didalam memenuhi kebutuhan pelayanan yang baik untuk para nelayan."

4. Nelayan pemilik perahu, Bpk. Tarman.

“ Pelayanan yang dilakukan oleh koperasi kepada para nelayan sudah dikatakan baik, seperti halnya pelayanan kesehatan dan juga proses pengamanan hasil tangkapan kami agar tidak hilang di curi orang juga sudah sangat baik."

5. Nelayan Buruh, Bpk walim.

“ Pelayanan sudah sangat baik dilakukan"

6. Tokoh masyarakat bpk. H. Udin

“ Saya kira untuk masalah pelayanan yang diberikan oleh koperasi sudah sangat baik, namun untuk proses pelayanan yang dilakukan pemerintah desa saya kurang faham. Tapi saya kira untuk hal ini dirasa sama saja seperti halnya proses pelayanan desa terhadap masyarakat."
Peneliti melihat bahwasannya pelayanan yang baik, yang di sebutkan oleh para informan ini hanya sebatas pelayanan yang diberikan oleh koperasi kepada nelayan. Namun proses pelayanan yang diberikan pemerintah terhadap masyarakat nelayan masih belum dapat dirasakan oleh nelayan secara langsung. Karena hal ini dikarenakan kewenangan yang dimiliki desa lewat LPMDes tersebut peranannya masih kalah dibandingkan dengan peran dari koperasi.

\subsection{Mengenali masalahan dan potensi}

\subsubsection{Mencari penyebab}

timbulnya masalah dalam
pemberdayaan

1. Ketua Lembaga Peberdayaan masyarakat Desa, desa Blanakan kabupaten Subang bpk. Toto Sugiarto SH.

“ Penyebab utama dari timbulnya masalah dalam hal pemberdayaan disini adalah kurangnya kewenangan yang kami miliki sebagai lembaga yang memiliki kewenangan untuk melakukan proses pemberdayaan, yang kedua proses pemberdayaan ini dirasakan sangat sulit dilakukan kepada masyarakat nelayan karena mainset dari nelayan tersebut. 
Bahwasannya ketika kita mencoba untuk melakukan penyuluhan ataupun pelatihan mereka suka menanyakan "ada uangnya tidak" sehingga mereka memilih untuk meninggalkan kegiatan-kegiatan yang tidak menghasilkan secara finansial.“

2. Sekertaris Desa Blanakan Bpk. Heri Susanto SH.

"Persoalan yang dihadapi dalam proses pemberdayaan seperti yang dijelaskan dalam pertanyaan yang sebelumnya adalah susahnya mengirimkan perwakilan nelayan untuk mengikuti penyuluhan dan pelatihan, karena memang hal ini mereka anggap membosankan dan tidak banyak membantu mereka ."

3. Sekertaris Koperasi Unit Desa Mina Fajar Sidik desa Blanakan Bpk. Dasam.

“Sejauh ini sih permasalahan yang sangat berarti tidak ada, mungkin sekarang kita sedang menghadapi persoalan alat tangkap. Dimana pemerintah melalui mentri perikanan dan kelautan melarang beberapa alat tangkap, sedangkan para nelayan ketika harus mengganti alat tangkap yang mereka punya dengan alat tangkap yang disarankan oleh pemerintah memerlukan biaya yang tidak murah. Namun hal itu perlahanlahan kita mulai mengatasi persoalan itu dengan memberikan pinjaman modal untuk mereka mengganti alat tangkap yang mereka miliki dengan alat tangkap yang disarankan oleh pemerintah."

4. Nelayan pemilik perahu, Bpk. Tarman.

“ Persoalan saya kira pasti ada saja, namun persoalan ini lebih bersifat teknis saja. Dimana harga ikan yang tidak stabil, cuaca yang tidak menentu, dan persoalan yang berarti saya kira tidak ada sejauh ini."

5. Nelayan Buruh, Bpk walim.

“ Pesoalan yang dihadapi sekarang adalah mengenai anjuran pemerintah tentang pelarangan beberapa alat tangkap, dimana memang hampir semua nelayan mengeluhkan hal itu. Di satu sisi kami tunduk dan takut terhadap aturan yang di keluarkan oleh pemerintah, tapi disisi lain anak isti kami membutuhkan penghasilan untuk melanjutkan hidup. Hal ini juga sudah kami bicarakan dengan pengurus koperasi, dan mereka memberikan beberapa solusi dengan memberikan pinjaman modal untuk membeli alat tangkap baru, namun kami masih 
mempertimbangkannya jangan sampai hutang kami juga banyak kepada koperasi sehingga berpengaruh kepada penghasilan kami utnuk dibawa kerumah.”

6. Tokoh masyarakat bpk. H. Udin

"Saya kira tidak ada yah."

Dari hasil wawancara diatas, peneliti menyimpulkan Beberapa persoalan yang menimbulkan kurangnya proses pemberdayaan dan persoalan-persoalan yang dihadapi dalam hal ini adalah : pertama, tidak adanya keikutsertaan pemerintah dalam hal ini pemerintahan desa melalui LPMDes didalam proses pemberdayaan masyarakat nelayan, hal ini lebih dikarenakan tidak adanya kerjasama yang dilakukan oleh pemerintah desa dengan koperasi sebagai bagain dari masyarakat nelayan. Kedua, Mainset masyarakat nelayan yang masih kurang terhadap pentingnya penyuluhan dan pelatihan yang mana akan meningkatkan pengetahuan mereka didalam menjalankan proses penangkapan ikan dilaut. Ketiga, peraturan pemerintah yang diberikan kepada masyarakat nelayan tidak dibarengi dengan solusinya, sehingga persoalan ini menjadi tanggungjawab pemerintah desa.

\subsubsection{Mencari faktor pendukung dan faktor penghambat dalam kegiatan pemberdayaan.}

1. Ketua Lembaga Peberdayaan masyarakat Desa, desa Blanakan kabupaten Subang bpk. Toto Sugiarto SH.

“ Saya rasa pertanyaan ini sama dengan pertanyaan sebelumnya, jadi intinya dari persoalanpersoalan yang saya sebutkan sebelumnya dijadikan bahan evaluasi dari situ kita bisa tahu apa yang akan kita lakukan selanjutnya.“

2. Sekertaris Desa Blanakan Bpk. Heri Susanto SH.

“ Kita harus memberdayakan kembali, masyarakat-masyarakat terdidik untuk ikut terjun langsung didalam menjawab persoalanpersoalan yang dihadapi bersama, tentunya kita bisa duduk bersama dengan pengurus kopersi dan sumber daya manusia yang kita miliki untuk mulai memikirkan persoalan-persoalan yang dihadapi. Karena kalau kita melihat potensi yang kita miliki disini sangat besar sekali, hanya membutuhkan kerjasama bersama didalam membangun ini semua." 
3. Sekertaris Koperasi Unit Desa Mina Fajar Sidik desa Blanakan Bpk. Dasam.

"Dalam hal ini jelas yang harus kita utamakan adalah mutu dari nelayan tersebut, sehingga ketika kita dihadapkan kedalam sebuah persoalan ini dapat di selesaikan bersama. Artinya bahwa harus adanya kesadaran dari nelayan sendiri tentang oersoalan bersama yang juga harus dicarikan solusinya bersama, karena selama ini semua persoalan selalu dilimpahkan kepada kami dan kami harus mencarikan solusinya sendiri. Yang mana terkadang solusi yang kami berikan tidak sesuai dengan keinginan mereka, tapi apa boleh buat hanya itu yang bisa kita perbuat karena kita tidak benar-benar tau apa yang sebenarnya mereka inginkan didalam memecahkan masalah tersebut.”

4. Nelayan pemilik perahu, Bpk. Tarman.

“ Mungkin harus mengoptimalkan kembali potensi-potensi yang dimiliki sehingga bisa maksimal.”

5. Nelayan Buruh, Bpk walim.

“Ya memperbaiki fasilitas-fasilitas yang sudah mulai rusak saja mungkin."
6. Tokoh masyarakat bpk. H. Udin

"Persoalan yang dihadapi sekarang adalah tidak adanya kerjasama yang harmonis antara koperasi dengan pemerintah desa, seolaholah mereka berjalan sendirisendiri. Kalau saja mereka bisa seiring sejalan membangun masyarakat nelayan dengan potensi-potensi yang dimilikinya, saya yakin masyarakat nelayan juga bisa disandingkan tarap kesejahteraannya dengan sektor perekonomian yang lain."

Pemberdayaan masyarakat nelayan oleh desa di wilayah ini mengalami kendala dikarenakan tidak adanya kerjasama dengan koperasi sebagai unit yang memang kosentrasi memberdayakan mereka. Potensi yang besar dimiliki oleh desa didalam mensejahterakan masyarakat nelayan, diantaranya dengan kelengkapan sarana dan prasarana yang mereka miliki, tentu akan mempermudah didalam melakukan sebuah peningkatan potensi sumberdaya manusia dan sumberdaya yang lainnya. Karena tujuan dari dilakukannya pemberdayaan tentu salah satunya adalah meningkatkan kualitas dari objek yang diberdayakan tersebut, dan pemberdayaan akan berhasil jika ditunjang dengan baik adanya sarana dan prasarana yang tersedia. 
Persoalan yang terjadi adanya tumpang tindih kewenangan antara pemerintah desa melalui LPMDes dengan koperasi, namun peneliti tidak melihat pesoalan ini menjadi masalah yang besar didalam proses pemberdayaan. Justru hal ini menjadi kekuatan besar yang dimiliki oleh desa didalam membangun masyarakat nelayan didalam melakukan pemberdayaan, dengan kata lain adanya kerjasama didalam mendisain konsep pemberdayaan yang mereka sepakati bersama tentu akan mempermudah dan mempercepat proses pemberdayaan yang dilakukan bersama. Peneliti sangat optimis sekali dengan adanya pemberdayaan yang dilakukan bersama antara desa dengan koperasi akan menjadikan masyarakat nelayan dapat disandingkan dengan sektor perekonomian yang lain, mengingat sarana dan prasarana yang dimiliki sangat memadai untuk menunjang keberhasilan unit usaha ini.

Program Pelatihan yang dilakukan setiap tahun harus tetap dilaksanakan sebagai bagian dari program pemberdayaan masyarakat nelayan, namun yang perlu diperhatikan didalam mengirimkan perwakilan untuk mengikutinya adalah orang yang berkecimpung langsung dibidang. Sehingga ilmu yang mereka dapatkan dapat diaplikasikan dilapangan, dan dapat mentransformasikan ilmu kepada para nelayan yang lain. Menyiapkan kaderkader terbaik yang dimiliki adalah hal terbaik didalam membantu proses pemberdayaan dan peningkatan kualitas SDM yang ada di daerah ini, dimana diharapkan dengan adanya kader-kader terbaik yang dikirimkan untuk mengikuti pelatihan dan penyuluhan dapat mempraktekan dan mentransformasikan ilmunya kepada orang-orang yang tidak mengikuti atau tidak mau ikut terlibat didalam proses penyuluhan dan pelatihan tersebut. Jadi dengan kata lain kegiatankegiatan yang berkaitan dengan pemberdayaan baik yang di selenggarakan oleh pemerintah maupun oleh koperasi bisa terserap dengan baik.

Kepala desa sebagai pembina di koperasi memiliki akses untuk mengawasi dan memberikan pertimbangan didalam mengeluarkan keputusan di koperasi. Namun yang perlu di ingat adalah kepala desa sebagai pembina tidak memiliki kewenangan yang lebih dibandingkan dengan ketua koperasi, karena unit usaha ini membawahi anggota, yang mana setiap keputusan harus dikonsultasikan terlebih dahulu kepada anggota. mungkin utnuk kedepannya ada sebuah singkronisasi kembali dan mengembalikan lagi bahwasannya koperasi masuk kedalam salah satu unit usaha milik desa yang pengelolaan dan wewenangnya ada juga di 
desa. Karena yang saya perhatikan koperasi adalah unit usaha yang mensejahterakan anggotanya, sedangkan kategori anggota menurut koperasi adalah orang-orang yang memiliki perahu atau perperan aktif didalam penjualan ikan di koperasi, bagaimana dengan para nelayan buruh yang notabene mereka hanya sebagai pelaksana lapangan (buruh). Menjadi pekerjaan rumah bersama untuk mensingkronkan kembali bagaimana proses kemitraan ini dapat berjalan dengan baik sehingga kesejahteraan di masyarakat nelayan bisa dirasakan bersama.

\section{KESIMPULAN DAN SARAN}

\section{Kesimpulan}

Berdasarkan hasil penelitian dan pembahasa mengenai pemberdayaan masyarakat pesisir (nelayan) desa Blanakan, kecamatan Blanakan, Kabupaten Subang jawa barat. Peneliti mengambil kesimpulan sebagai berikut :

1. Pemberdayaan masyarakat nelayan oleh LPMDes desa Blanakan Kabupaten Subang tidak berjalan dengan baik, hal ini dikarenakan tidak adanya kegiatan pemberdayaan yang dilakukan oleh LPMDes. Pemberdayaan cenderung lebih banyak dilakukan oleh Koperasi unit desa, walaupun pemberdayaan ini masih di lingkup yang sangat kecil (nelayan pemilik perahu). hal ini juga yang membuat pemerintah desa tidak melalukan pemberdayaan, karena menganggap semuanya sudah dilakukan oleh koperasi sebagai lembaga induk dari masyarakat nelayan. Tidak adanya singkronisasi antara pemerintahan desa (LPMDes) dengan koperasi juga menjadi salah satu permasalahan tidak adanya proses pemberdayaan masyarakat nelayan. Peneliti melihat adanya

2. Potensi besar yang dimiliki tidak dimanfaatkan dengan baik didalam melakukan pemberdayaan, sarana dan prasarana yang ada di tempat ini sudah sangat memadai untuk melakukan sebuah peningkatan sumberdaya, namun tidak dimanfaatkan dengan baik. Sehingga masyarakat nelayan masih tidak dapat disandingkan dengan sektor ekonomi lain. Sarana dan prasarana mulai dari tempat penjualan ikan yang sangat besar dan tertata rapih, tempat pengisian solar, tempat bersandar kapal yang sangat baik, mobil ambulance, kepemilikan pabrik es (untuk mengawetkan hasil tangkapan), semuanya terdapat di wilayah ini. Dimana tidak semua wilayah nelayan memiliki fasilitas sarana dan prasarana yang baik. Namun semua sarana dan prasarana 
tersebut terkesan hanya di perjuangkan atau dihasilkan oleh kerja keras dari koperasi semata.

3. Pola fikir masyarakat nelayan yang masih kurang terhadap pentingnya manfaat dari pemberdayaan baik itu bersifat penyuluhan dan pelatihan ataupun kegiatan pemberdayaan lainnya yang mana akan meningkatkan pengetahuan mereka didalam menjalankan proses penangkapan ikan dilaut. Hal ini juga menjadi aktor pengambat terhadap tidak berjalannya proses pemberdayaan yang dilakukan.

\section{Saran}

Peran LPMDes didalam proses pemberdayaan masyarakat nelayan sangatlah kurang berjalan, namun melalui Kepala desa sebagai pembina di koperasi memiliki akses untuk mengawasi dan memberikan pertimbangan didalam mengeluarkan keputusan di koperasi. Namun yang perlu di ingat adalah kepala desa sebagai pembina tidak memiliki kewenangan yang lebih dibandingkan dengan ketua koperasi, karena unit usaha ini membawahi anggota, yang mana setiap keputusan harus dikonsultasikan terlebih dahulu kepada anggota. mungkin utnuk kedepannya ada sebuah singkronisasi kembali dan antara koperasi dengan pemerintahan desa untuk mengkonsep bersama proses pemberdayaan yang akan di jalankan bersama, sehingga tidak ada lagi saling mengandalkan untuk proses pemberdayaan. Karena yang hasil wawancara dan pembahawsan peneliti menemukan adanya proses yang dominan didalam pemberdayaan yang dilakukan oleh koperasi, namun kosentrasi mereka adalah anggota, sedangkan kategori anggota menurut koperasi adalah orangorang yang memiliki perahu atau berperan aktif didalam penjualan ikan di koperasi, bagaimana dengan para nelayan buruh yang notabene mereka hanya sebagai pelaksana lapangan (buruh). Hal ini menjadi pekerjaan rumah bersama untuk mensingkronkan kembali bagaimana proses kemitraan ini dapat berjalan dengan baik sehingga kesejahteraan di masyarakat nelayan bisa dirasakan bersama, tidak hanya dilakukan oleh koperasi namun juga oleh pemerintah dan lebih memperluas objek pemberdayaannya lagi, agar kesejahteraan dapat dirasakan bersama bukan hanya pemiliki perahu tapi juga bagi buruh nelayan.

Dalam penelitian yang berikutnya, mungkin akan lebih baik mencari jalan agar bagaimana konsep pemberdayaan masyarakat nelayan ini dapat dilakukan bersama. Sehingga tidak ada tumpang tindih didalam pelaksanaan pemberdayaan masyarakat nelayan di desa Blanakan kabupaten subang. Dengan adanya konsep bersama yang disepakati untuk melakukan 
pemberdayaan, peneliti optimis bahwasannya pemberdayaan dmasyarakat nelayan di wilayah ini akan berjalan dengan baik dan sesuai dengan konsep pemberdayaan yang diharapkan.

\section{DAFTAR PUSTAKA}

\section{Referensi Buku}

Agus Salim. 2001. Tori dan Paradigma Penelitian Sosial. Yogyakarta: Tiara Wacana

Charles AT. 2001. Sustainable fishery systems. Canada: Blakwell Science Ltd. 370 p.

Craig, G. and Mayo, M. (eds) (1995) Community Empowerment. A Reader in Participation and Development. London: Zed Books. Pp. 1-11.

Dault A. 2008. Pemuda Dan Kelautan. Jakarta: Pustaka Cidesindo. 222 hlm.

Hikmat A, 2006, Strategi Pemberdayaan Masyarakat. Bandung: Humaniora Utama Press. 240 hlm.

Ife, Jim. 1995. Community Development: Creating Community Alternatives Vision, Analysis and Practice. Australia: Longman. 297 p.

Kusnadi, Sumarjono, Sulistiowati, Yunita, Subchan, Puji. 2007. Strategi Hidup Masyarakat Nelayan. Yogyakarta: LKiS Pelangi Aksara.
2003. Akar Kemiskinan Nelayan. Yogyakarta: LKiS Pelangi Aksara.136 hlm. 2009. Keberdayaan Nelayan dan Dinamika Ekonomi Pesisir. Pusat Penelitian Wilayah Pesisir Dan Pulau-Pulau Kecil. Jember: Lembaga Penelitian Universitas Jember. 152 hlm.

Mc Ardle, J. (1989), “Community Development Tools of Trade". Community Quar-terly Journal 16: 47-54 p.

Moleong Lexy.j. 2007. Metode Penelitian Kualitatif. Bandung: Remaja Rosdakarya

Mulyadi S. 2007. Ekonomi Kelautan. Jakarta: PT Raja Grafindo Persada. $148 \mathrm{hlm}$.

Satria A. 2001. Dinamika Modernisasi Perikanan: Formasi Sosial dan Mobilitas Nelayan. Bandung: Humaniora Utama Press. 153 hlm.

Siswanto B. 2008. Kemiskinan dan Perlawanan Kaum nelayan. Malang: Laksbang Mediatama. Hlm 193-216. Suharto E, 2005, Membangun Masyarakat Memberdayakan Rakyat. Kajian Strategi Pembangunan Kesejahteraan 
Sosial dan Pekerjaan Sosial.

Bandung: PT Refika Aditama.

Suhendra. 2006. Peranan birokrasi dalam

pemberdayaan masyarakat. Bandung:

Alfabeta.

Widodo J dan Suadi. 2006. Pengelolaan

Sumberdaya Perikanan Laut.

Yogyakarta: Gajah Mada University

Press. $252 \mathrm{hlm}$.

\section{Datar-Data}

1. Data Anggota Nelayan KUD Mina Fajar Sidik Blanakan Tahun 2013

2. Profil Desa Blanakan Tahun 2014 Lampiran 2.

\section{Pedoman Wawancara}

\section{Badan Pemberdaya Masyarakat \\ (BPD) Desa Blanakan}

1. Sejauh mana BPD terlibat didalam masalah peningkatan perokonomian masyarakat (Nelayan) ?

2. Proses pemberdayaan apa yang dilakukan oleh BPD didalam meningkatkan tarap kehidupan perekonomian masyarakat?

3. Didalam proses pemberdayaan, konsep pemberdayaan yang seperti apa yang dilakukan?

4. Adakah kendala yang dihadapi oleh BPD didalam menjalankan proses pemberdayaan masyarakat?
5. Apa solusi yang ditawarkan oleh BPD didalam menjawab kendala dan tantangan pemberdayaan masyarakat (nelayan)?

3. Masyarakat (Nelayan, Tokoh Masyarakat, Tokoh Agama, Tokoh Pemuda, dan berbagai organisasi yang bergerak di bidang Perikanan)

1. Adakah keterlibatan BPD didalam proses peningkatan perekonomian kehidupan Nelayan?

2. Proses pemberdayaan seperti apa yang dilakukan oleh BPD yang pernah dilakukan didalam meningkatkan tarap perekonomian masyarakat?

3. Apakah proses pendekatan pemberdayaan yang dilakukan oleh BPD sudah sesuai dengan harapan?

4. Apakah anda dilibatkan didalam proses pemberdayaan yang dilakukan oleh BPD, baik dalam proses perencanaan pemberdayaan (Konsep) ataupun proses pelaksanaan pemberdayaannya (sosialisasi) ?

5. Adakah proses pemberdayaan yang anda tawarkan kepada BPD dan dilaksanakan oleh BPD? 